\title{
2 Trade Liberalization and Competitive Structure in Turkey during the 1980 s
}

\author{
Sübidey Togan
}

\section{INTRODUCTION}

All present-day industrial and developing countries have, at one time or another, protected their manufacturing industries. Turkey is no exception. It has protected import-substituting industries over exports and industry over agriculture during the three decades 1950-79. During this period, Turkey followed an inward-oriented development strategy. Until the mid-1960s it was engaged in replacing the imports of nondurable consumer goods by domestic production. By the mid-1960s Turkey was able to satisfy the domestic demand for those commodities. It then had a choices of two strategies: it could either embark on exportation of manufactured goods, or it could move on to the second stage of import substitution. Turkey chose the latter strategy and replaced the imports of intermediate goods and consumer durables by domestic production. But these commodities had different characteristics from those replaced at the first stage. They were highly capital intensive, they required the availability of skilled and technical labour and were subject to economies of scale, with efficient plant size being large compared to domestic needs. Correspondingly high protection of these industries was required. High protection was achieved through tariffs, quotas and over-valued exchange rates. As a result, the incremental capital output ratio increased considerably and eventually the maintenance of the pace of growth became more and more costly.

The quadrupling of oil prices between 1973 and 1974 and the 19745 world recession adversely affected the Turkish economy. The oil bill rose sharply. The economic difficulties of the European economies led to a slowdown of emigration and a decline in workers remittances. Despite the external shocks amounting, according to Balassa (1981), to 5.4 per cent of GNP, Turkey attempted to preserve its growth momentum through rapid reserve decumulation and massive external borrowing. 
Successive governments refused to adapt their economic strategies to the new environment and pursued expansionary policies. Under the impetus of the public sector, investment programmes grew sharply. The investment/GNP ratio increased from about 19.1 per cent in 1973 to 24.1 per cent in 1977 . Since consumption was not simultaneously constrained, GNP grew at the unsustainable rate of 7.8 per cent per annum during 1974-6. The gap between national savings and investment widened. During this period, when financial markets were repressed by way of mandatory ceilings on deposit and borrowing rates, the public finances deteriorated sharply. As public investment programmes increased considerably, the government also imposed policies such as under-indexation of the prices of public enterprises and over-employment by these institutions. These policies, in turn, caused dramatical deterioration of the accounts of state economic enterprises. As a result, the public sector borrowing requirements increased to about 11.7 per cent of GNP in 1977. Money supply and, hence, inflation exploded. The government, in order to keep the inflation rate from increasing further, kept essentially to a fixed exchange-rate system. Although Turkey introduced a series of minor exchange-rate adjustments, the spread between Turkish and world-wide inflation rate increased. The real exchange rate appreciated. The government tried to avoid the adverse effects of the exchange-rate appreciation by increases in export rebate rates and increased control on foreign capital movements. But as a result of the policies followed, imports grew and exports stagnated. By 1977 the net capital inflow was nearly double that of export value. The heavy borrowing soon led to high external debt. The share of short-term debt increased rapidly. Consequently, the widening current account deficit developed into a payments crisis in 1977 and Turkey lost its international creditworthiness. Shortage of foreign exchange restricted the inflow of imports that were required for production as well as capacity expansions needed for future growth. The crisis was accompanied by recession and also political instability. By late 1970s it was apparent that the strategy followed was no longer sustainable.

In January 1980, the government introduced a comprehensive policy package designed to restore price stability, achieve viable growth, increase the efficiency of resource allocation through greater reliance on market forces and introduce 'outward orientation' in economic policy.

The stabilization programme introduced in January 1980 made use of a wide range of policy instruments. The financial position of state economic enterprises was improved through a combination of price increases, reduction in wage expenditure and scaling down of invest- 
ment programmes. The budget deficit was reduced by widening the income tax base, raising some indirect tax rates and improving tax collection procedures. Monetary policy was tightened. Action was taken to increase the efficiency of the financial system and foreign trade and foreign exchange movements were liberalized to a very large extent. The liberalization episode that began in January 1980 marks a turning point in Turkish economic history. For the first time in its recent history, the country aimed explicitly at making the economy more 'market oriented'.

The purpose of this paper is to analyze quantitatively the trade liberalization episode to Turkey's liberalization experience that began during the 1980s. In Section 2 we consider the characteristics of the Turkish foreign trade regime, and in Section 3 the competitive structure of the Turkish economy. The paper concludes with policy recommendations towards the rationalization of the Turkish foreign trade system.

\section{TRADE LIBERALIZATION}

A trade system is called neutral if it operates under perfect competition as it would in the absence of government interference. Any movement in a trade regime towards neutrality is defined as trade liberalization, and a change which increases the deviation from neutrality is seen as reversal of liberalization. Trade liberalization, thus defined, manifests itself in three ways. First, trade liberalization is a move from rationing through government regulation to the use of price mechanisms in the form of tariffs. Second, a move towards neutrality lowers the average levels of nominal and effective protection and subsidy rates and reduces the dispensions within the system of these rates. The third manifestation of trade liberalization is a move towards a system where the real exchange rate and the sectoral real effective exchange rates remain relatively stable over time with no violent fluctuations.

\subsection{Import regime}

In the immediate post-war years, Marshall aid was granted to Turkey, and Turkey became a member of the Organization for European Economic Cooperation, thus promoting Turkey's ties with the West. In 1950s, the anti-etatist Democratic Party took power from the, until then, monopolistic Republican Party. At the beginning of the 1950s, the government followed liberal policies. But after the massive crop failure of 
1954, the country turned to import substituting policies, and hence to protectionist foreign trade policies. Licensing was to be required for all imports, with many import commodities transferred to the quota list. All importers were required to possess an 'importer's certificate', and a system of multiple exchange rates was inaugurated. In 1954, Turkey replaced specific tariff rates with ad valorem rates, and tariff rates were increased considerably as reported by Baysan and Blitzer (1988).

In 1958, the government agreed on a stabilization programme prepared with the assistance of the IMF. The Turkish lira was devalued and Turkey moved towards a more unified exchange-rate system. The various separate lists of imports were replaced by import programmes, which stated import regulations and procedures that importers had to follow to obtain import licenses. The first import programme appeared in the Official Gazette on 23 September 1958. Thereafter, import programmes became the major instrument of import control.

During the 1960 s, a new, socially progressive constitution was adopted. The constitution required the establishment of the State Planning Organization and formal economy-wide planning through five-year plans and annual programmes. With the introduction of economy-wide planning, economic policy exhibited greater concern for industrialization. During this period, Turkey explicitly followed an inward-oriented development strategy through high protection of industry. High protection was achieved through restrictions, regulation, tariffs, quotas and overvalued exchange rates.

During the 1960s and 1970s, all imports into Turkey were regulated by annual import programmes. Each programme was published in the Official Gazette. The import programme itemized commodities under the liberalization list, the quota list, and a list enumerating the commodities to be imported under bilateral trade arrangements. Importation of goods not enumerated in any of the lists was prohibited. Of these lists, the quota list and the liberalization list were of major importance. The liberalized lists contained commodities considered essential for the achievement of development plan objectives when domestic productive capacity was unavailable. They consisted mostly of capital goods and raw materials. The liberalization list was further divided into a free import list (liberalization list I) and a restricted list (liberalization list II). Commodities on the free import list consisted mainly of raw materials and spare parts, while commodities on the restricted list were mainly processed and semi-processed goods and raw materials.

The quota list covered commodities of which there was some domestic production or which were considered not essential by plan objec- 
tives such as consumer goods. As soon as domestic production of an import competing product began, the import was transferred from the liberalized list to the quota list. When domestic production of a commodity was sufficient to meet the domestic demand, the item was removed from the quota list. Since commodities not specified on the import lists could not be imported, complete protection was then granted to local producers.

Importers wishing to import any commodity on liberalization lists I and II during the 1960s and 1970s had to go through a complex set of procedures. Procedures for items of liberalization list I were simpler than those for items on liberalization list II, which in turn were simpler than those on the quota list items.

Anyone wishing to import a liberalized list I item had to first obtain an 'importer's certificate' from the local Chamber of Industries or the Chamber of Commerce. The Chamber issued the certificate as long as the person was a bona fide producer or wholesaler. The certificate entitled the holder to select items relevant to the holder's business. Once the import programme was announced, the holder of an 'importer's certificate' valid for commodities on liberalization list I could make an application for an import licence from the Central Bank. The applicant gave the description of the goods he wished to import, the quantity and the unit price. He made a 'guarantee deposit' at the local bank, which would be transferred to the Central Bank. The guarantee deposit rates varied over time. They amounted in 1966 to 70 per cent for items on liberalization list I, 100 per cent for items on liberalization list II, and 10-30 per cent for items on the quota list. Thereafter, the Central Bank issued import permits for the amount applied for on a 'first-come, first-served' basis as long as foreign exchange was available. A licence, once issued, constituted a valid claim against foreign exchange. To import the commodity the holder of the import permit had to have a letter of credit in hand. The importer having the import permit and letter of credit could place his/her order. When the goods arrived at the customs office, the custom officials checked whether the imported items conformed to the description on the import permit. The importer then paid all duties and surcharges associated with importation and cleared the goods from customs.

An importer wishing to import items on liberalization list II had to obtain, in addition to the procedures described above, the approval of a government agency prior to the issuance of an import licence. The purpose of the 'permission certificate' was to increase the difficulties associated with importing, and thus to restrict imports. The import 
programme specified the government agency the 'permission certificate' had to be obtained.

In the case of imports of goods on the quota list, the procedures were more complex than either of the liberalization list procedures. To study the procedures, first one must consider the way the value of each quota item in the import programme was determined. In that process, the State Planning Organization, the Ministry of Commerce, the Central Bank, the Ministry of Finance and the Union of Chambers of Commerce and Industry took part. The Union represented the interests of the private sector, whereas the Ministry of Finance represented the interests of public sector enterprises. There were two type of quotas: commodity specific and user specific. The commodity specific quotas were further allocated between industrialists and importers. Importers were those who imported for the purpose of resale without processing, whereas industrialists were those who were using the quota goods in their own production process. Legally, imports to industrialists could not be resold. Each commodity specific quota value was subdivided into the amount to be allocated to industrialists and the amount for importers. On the other hand, the user specific quotas were divided into investment goods quotas and those covering the needs of certain assemblers and manufacturers. Goods imported under these quotas required the approval of the State Planning Organization to insure that the activities were in conformity with the plan objectives.

Allocation of quotas after the publication of quotas followed different procedures for industrialists and importers. in the case of industrialists, the public and private sector shares of individual quotas were first worked out by the relevant ministries and Union of Chambers. Once the private sector share was determined, the problem was to allocate the amount among the industrialists. At that stage, we may note that some of the items in the import programmes were designated as being subject to the control of individual ministries. When no ministry was specified the application was made to the local chamber of industry which forwarded it to the Union of Chambers. Industrialists wishing to import those items applied to the relevant ministry for a 'requirements certificate'. These certificates were issued in proportion to the plant capacities of the applicants. The amount allocated to each importer was shown on the 'requirements certificate'. This certificate was forwarded to the Central Bank, with which the Central Bank issued the import license. On the other hand, the allocation procedures in the case of importers were simpler. Once the import list were published, importers made their requests with an authorized bank, which forwarded 
the application to the Central Bank. The Central Bank summed the value of requests by quota categories, and when the sum exceeded the quota, the bank allocated the quotas by scaling down proportionately so that the quota was filled.

Imports were subject to tariffs and tariff-like charges. The latter consisted, as reported in Krueger (1974), Baysan and Blitzer (1991) and Krueger and Aktan (1992), mainly of the municipality tax, stamp duty, wharf tax and production tax.

The import regime explained above remained in force until the 1980s. In 1981, the quota list was partly phased out. In that year a large number of commodities were transferred from 'liberalization list II' to 'liberalization list I'. A major reform was introduced in January 1984, when all imports were classified into three lists: the 'prohibited list', 'imports subject to permission' and 'liberalized list'. Commodities that could not be imported under any circumstances, such as arms and ammunition, were specified in the 'prohibited list'. 'Imports subject to permission' specified the items that could be imported with prior official permission, and the 'liberalized list' enumerated the commodities that could be freely imported.

At the time of the import system reform, the government replaced the production tax, which applied to domestic production and import of certain commodities, with the value added tax (VAT), which applied to almost all commodities. Moreover, it imposed a new surcharge, the 'housing fund tax', on some imports to finance housing construction for poor and middle-income families. In addition, two surcharges on imports were imposed under the titles of the 'support and price stabilization fund tax' and 'resource utilization support fund tax'. Thereafter, the import duty and housing fund tax rates were revised at least once every year during the 1985-92 period.

During the 1980s, imports were subject to tariffs and several tarifflike charges: the municipality tax, transportation infrastructure tax, mining fund tax, stamp duty, value added tax, housing fund tax, resource utilizatin and support fund tax, and support and price stabilization fund tax.

\subsubsection{Quantitative restrictions}

As emphasized above, the quota list specified the dollar value of imports and implied a binding quantitative restriction on imports. It was partly phased out in 1981 . Table 2.1 shows the share of commodities in the 'restricted list' (liberalization list II) in total imports. As can be seen from the table, the share of commodities in the 'restricted list' 
TABLE 2.1 Share of 'restricted list' imports in total imports

\begin{tabular}{lccc}
\hline & $\begin{array}{c}\text { Restricted imports } \\
\text { (million US \$) }\end{array}$ & $\begin{array}{c}\text { Total imports } \\
\text { (million US \$) }\end{array}$ & $\begin{array}{c}\text { Share of restricted } \\
\text { imports in total } \\
\text { imports (\%) }\end{array}$ \\
\hline 1970 & 192 & 948 & 20.3 \\
1971 & 260 & 1171 & 22.2 \\
1972 & 413 & 1563 & 26.4 \\
1973 & 478 & 2086 & 22.9 \\
1974 & 697 & 3778 & 18.4 \\
1975 & 1163 & 4739 & 24.5 \\
1976 & 1143 & 5129 & 22.3 \\
1977 & 1160 & 5796 & 20.0 \\
1978 & 784 & 4599 & 17.0 \\
1979 & 973 & 5069 & 19.2 \\
1980 & 947 & 7909 & 12.0 \\
1981 & 831 & 8933 & 9.3 \\
1982 & 272 & 8843 & 3.1 \\
1983 & 163 & 9235 & 1.8 \\
1984 & 17 & 10757 & 0.2 \\
\hline
\end{tabular}

SOURCE: Various issues of the Annual Report, Central Bank of Turkey.

declined from 24.5 per cent in 1974 to 9.3 per cent in 1981 and 1.8 per cent in 1983.

In 1984, a major trade reform was introduced, when all imports were classified into three lists: the 'prohibited list', the 'imports subject to permission list' and the 'liberalized list'. Prior to 1984, a large number of commodities had already been transferred, starting with the 1981 import regime from the restricted list (liberalization list II) to the free import list (liberalization list I).

The 'prohibited list', introduced in 1984 , originally contained about 500 commodities. The number of these commodities decreased substantially in the following year; the number was reduced to three in 1985 and was kept thereafter at that level.

Table 2.2 shows the share of commodities in the list imports subject to permission'. As can be seen from the table, this list constituted about 46.5 per cent of all imports in 1984. The share declined to 21.9 in 1986 and 6.1 per cent in 1988. In 1984, the list covered a wide range of commodities, but by 1988 it was used in only 11 of the 49 sectors, the most important of which included the pharmaceutical products, printing and publishing, and other non-metallic mineral products sectors. In the case of pharmaceutical products, the share of imports 
TABLE 2.2 Share of imports 'subject to permission' in sectoral imports (\%)

\begin{tabular}{|c|c|c|c|c|c|}
\hline $\begin{array}{l}\text { I-O } \\
\text { code }\end{array}$ & Sector name & 1984 & 1986 & 1988 & Total \\
\hline 1 & Agriculture & 0.10 & 1.90 & 0.00 & 100 \\
\hline 2 & Animal husbandry & 10.55 & 1.40 & 0.00 & 100 \\
\hline 3 & Forestry & 0.00 & 0.00 & 0.00 & 100 \\
\hline 4 & Fishery & 0.00 & 90.62 & 0.00 & 100 \\
\hline 5 & Coal mining & 0.44 & 0.00 & 0.00 & 100 \\
\hline 6 & Crude petroleum & 100.00 & 0.00 & 0.00 & 100 \\
\hline 7 & Iron ore mining & 0.00 & 0.00 & 0.00 & 100 \\
\hline 8 & Other met. ore mining & 0.00 & 0.00 & 0.00 & 100 \\
\hline 9 & Non-metallic mining & 50.40 & 48.25 & 0.00 & 100 \\
\hline 10 & Stone quarying & 0.00 & 0.00 & 0.00 & 100 \\
\hline 11 & Slaughtering \& meat & 0.00 & 25.99 & 0.00 & 100 \\
\hline 12 & Fruits \& vegetables & 0.00 & 0.41 & 0.00 & 100 \\
\hline 13 & Vegetable \& animal oil & 0.00 & 0.00 & 0.00 & 100 \\
\hline 14 & Grain mill products & 0.00 & 4.33 & 0.00 & 100 \\
\hline 15 & Sugar refining & 3.41 & 53.10 & 0.00 & 100 \\
\hline 16 & Other food processing & 0.25 & 1.10 & 0.00 & 100 \\
\hline 17 & Alcoholic beverages & 94.52 & 0.04 & 0.00 & 100 \\
\hline 18 & Non-alcoholic beverages & 0.00 & 100.00 & 0.00 & 100 \\
\hline 19 & Processed tobacco & 0.00 & 100.00 & 0.00 & 100 \\
\hline 20 & Ginning & 0.00 & 0.00 & 0.00 & 100 \\
\hline 21 & Textiles & 7.95 & 3.71 & 0.00 & 100 \\
\hline 22 & Clothing & 0.00 & 41.95 & 0.00 & 100 \\
\hline 23 & Leather \& fur products & 0.00 & 0.08 & 0.00 & 100 \\
\hline 24 & Footwear & 0.00 & 0.00 & 0.00 & 100 \\
\hline 25 & Wood products & 1.33 & 0.26 & 0.00 & 100 \\
\hline 26 & Wood furniture & 0.00 & 100.00 & 0.00 & 100 \\
\hline 27 & Paper \& paper products & 0.08 & 7.47 & 6.18 & 100 \\
\hline 28 & Printing \& publishing & 0.03 & 39.64 & 39.41 & 100 \\
\hline 29 & Fertilizers & 0.00 & 9.28 & 0.00 & 100 \\
\hline 30 & Pharmaceutical products & 0.00 & 48.18 & 49.34 & 100 \\
\hline 31 & Other chemical products & 0.00 & 9.74 & 5.58 & 100 \\
\hline 32 & Petroleum refining & 99.09 & 0.00 & 0.00 & 100 \\
\hline 33 & Petroleum \& coal products & 0.00 & 0.00 & 0.00 & 100 \\
\hline 34 & Rubber products & 27.22 & 5.43 & 0.00 & 100 \\
\hline 35 & Plastic products & 93.13 & 94.23 & 0.00 & 100 \\
\hline 36 & Glass \& glass products & 12.38 & 20.56 & 0.00 & 100 \\
\hline 37 & Cement & 0.00 & 0.00 & 0.00 & 100 \\
\hline 38 & Non-metallic mineral & 53.28 & 32.40 & 30.29 & 100 \\
\hline 39 & Iron \& steel & 91.29 & 62.95 & 20.57 & 100 \\
\hline 40 & Non-ferrous metals & 83.10 & 83.70 & 12.35 & 100 \\
\hline 41 & Fabricated metal products & 65.51 & 49.53 & 0.05 & 100 \\
\hline
\end{tabular}


TABLE 2.2 continued

\begin{tabular}{|c|c|c|c|c|c|}
\hline $\begin{array}{l}I-O \\
\text { code }\end{array}$ & Sector name & 1984 & 1986 & 1988 & Total \\
\hline 42 & Non-electrical machinery & 52.90 & 18.47 & 5.11 & 100 \\
\hline 43 & Agricultural machinery & 46.63 & 7.38 & 0.00 & 100 \\
\hline 44 & Electrical machinery & 31.95 & 31.67 & 13.09 & 100 \\
\hline 45 & Shipbuilding \& repairing & 100.00 & 95.42 & 0.00 & 100 \\
\hline 46 & Railroad equipment & 0.00 & 0.00 & 0.00 & 100 \\
\hline 47 & Motor vehicles & 58.48 & 57.08 & 13.39 & 100 \\
\hline 48 & Other transport equipment & 1.24 & 1.24 & 0.00 & 100 \\
\hline 49 & Other man. industries & 20.44 & 22.61 & 0.01 & 100 \\
\hline \multicolumn{2}{|l|}{ Mean } & 46.46 & 21.86 & 6.08 & 100 \\
\hline
\end{tabular}

SOURCE: Author's calculations.

subject to permission was about 48.2 per cent of all sectoral imports in 1986 , and 49.3 per cent in 1988.

By 1990 all of the different types of quantitative restrictions were completely phased out.

\subsubsection{Nominal and effective protection rates}

It is well known that in the absence of quantitative restrictions and foreign exchange controls, quota premiums will disappear. Hence any divergence between domestic ex-factory price and the tariff-inclusive landed cost of an imported commodity can be attributed to the trade margins of the wholesalers. This means that tariffs, levies and other expenses, e.g. the tariff equivalent of guarantee deposits required for imports, will represent the nominal protection rate (NPR) on the commodity.

Economists have long recognized that the profitability of a business activity can be changed by measures which affect the selling price of the final product, the costs of the intermediate material inputs, or a combination of both. The literature on effective protection maintains that when there are intermediate inputs, effective protection to value added is what matters and not the nominal protection. Put another way, if both the final product and the material inputs used to process that product can be bought or sold on world markets at given prices, under free trade conditions and with a given exchange rate, this would provide a certain value added (cost of labour, land and capital inclusive of an acceptable profit margin). Tariffs and tariff-like charges alter the 
product price and the cost to the enterprise of the intermediate inputs, thus widening or narrowing the value added. Effective protection is simply the difference between the observed value added at tariff inclusive domestic prices and what the value added would be under free trade at world prices; and the effective protection rate is this difference expressed as a proportion or percentage of the free trade value added.

Table 2.3 provides estimates of nominal and effective protection rates. The nominal protection rates have been obtained under the assumption that there are no quantitative restrictions and that quota premiums are zero. From Table 2.3 it can be seen that the economy-wide nominal protection rate (NPR) has declined from 70.2 per cent in 1984 to 28.3 per cent in 1991. Noting the fact that quantitative restrictions had been eliminated completely by the end of 1980 s, the reductions in nominal protection rates have been larger than indicated above. Similarly, the economy-wide effective protection rate (EPR) declined from 74.71 per cent in 1984 to 38.38 per cent in 1991 . More significantly, recent policies have narrowed the inter-industry distribution of the NPR and EPRs, as evidenced by the values of standard deviation figures for NPR and EPR. When determining the average rates, we have weighted the sectoral nominal rates by sectoral outputs valued at world prices, and the sectoral effective rates by sectoral value added evaluated at world prices.

The most striking conclusion to be derived from Table 2.3 relates to the height of protection in Turkey. From the table we note that, among the 49 tradeable goods industries considered, there were 30 industries in 1983, 32 in 1984, 24 in 1988, 11 in 1990 and eight in 1991 which had NPRs higher than 50 per cent. On the other hand, there were five industries in 1983, three in 1984, seven in 1988, 15 in 1990 and 17 industries in 1991 which had NPRs less than 20 per cent. A similar consideration applies to the EPRs. There were 27 industries in 1983, 30 in 1984, 28 in 1988, 24 in 1990 and 23 industries in 1991 which had EPRs greater than 50 per cent. Similarly, there were seven industries in 1983, six in 1984, eight in 1988, nine in 1990 and eleven industries in 1991 which had non-negative EPRs less than 20 per cent. There were two industries in 1983, 1984 and 1988, which had negative EPRs between 0 and - 100 per cent; and the number of sectors with EPRs less than - 100 per cent amounted to four in 1983, three in 1984, two in 1988, zero in 1990 and one in 1991.

After having shown the level of protection we now turn to a more detailed examination of the characteristics of tariff revisions. For this purpose we compare the 1983 figures with the average of 1990-1 figures. 


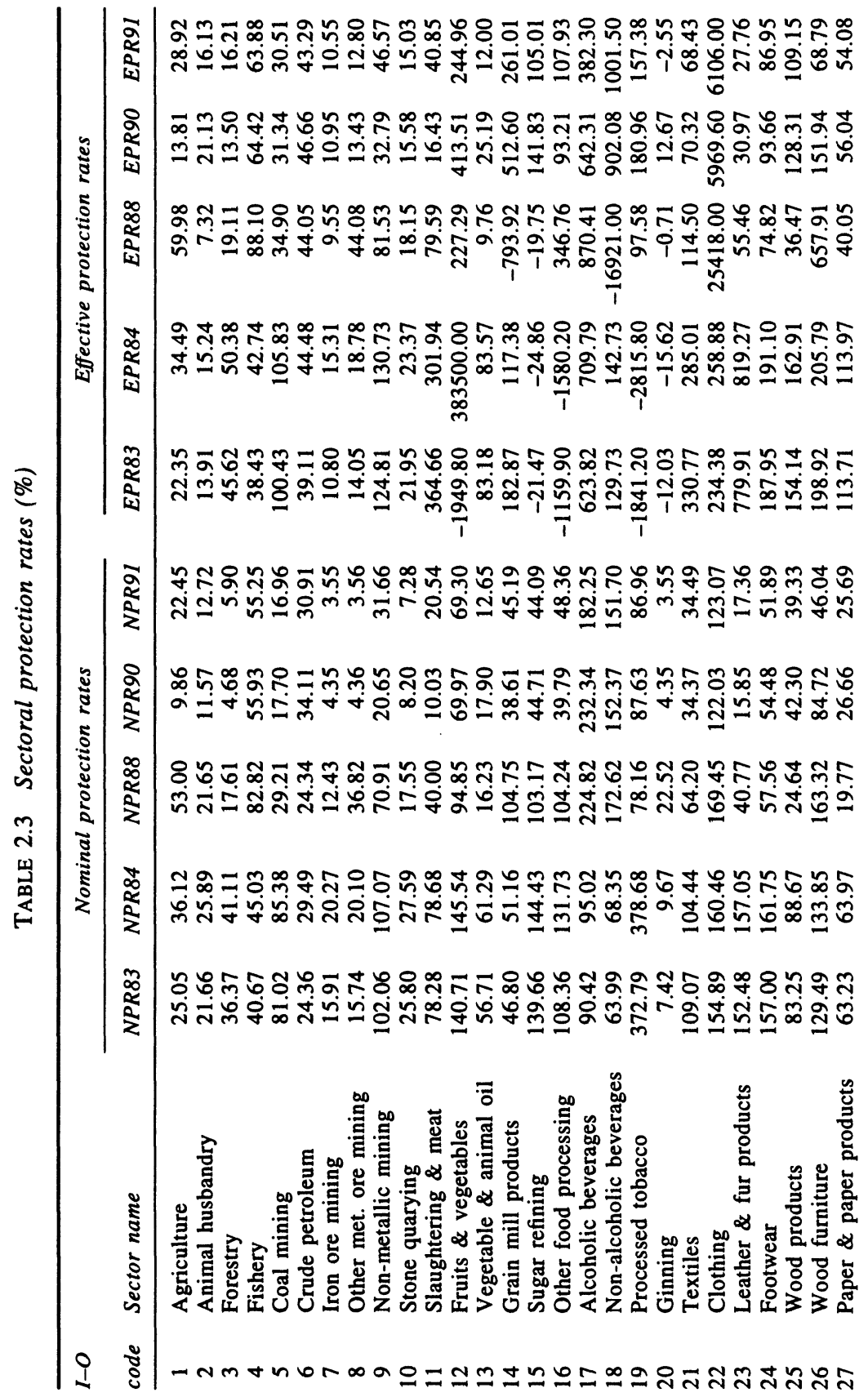




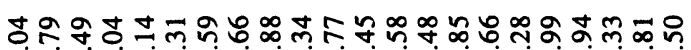

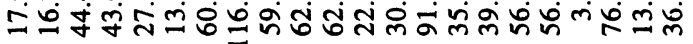

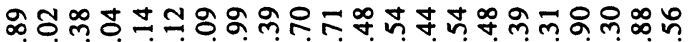

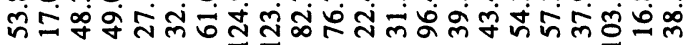

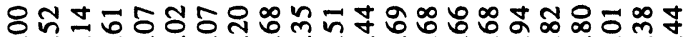

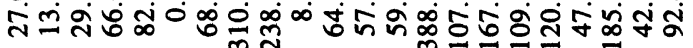

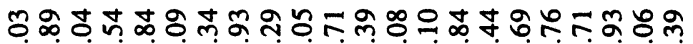

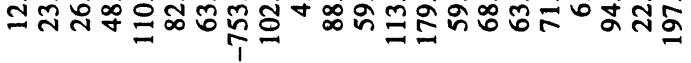

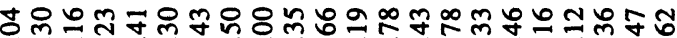

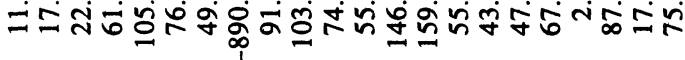

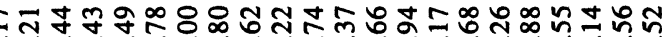

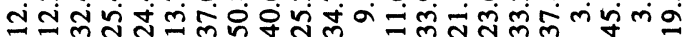

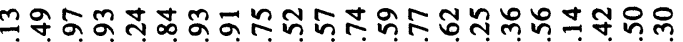

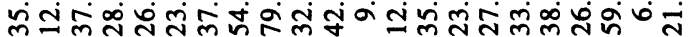

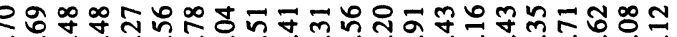

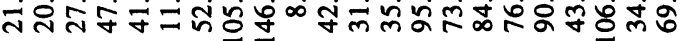

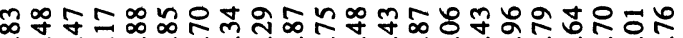

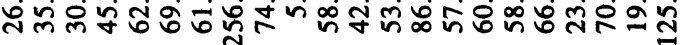

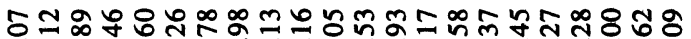

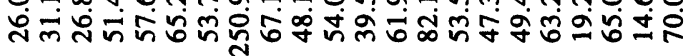

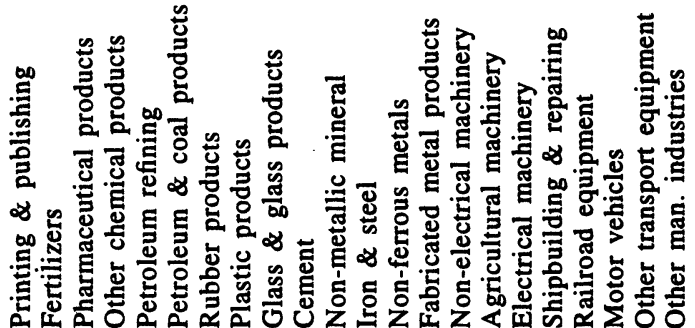

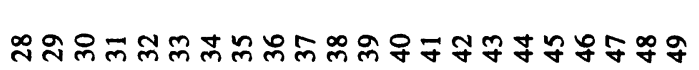


First, we note that in 1983 the highest NPR, were granted to the following sectors; processed tobacco and products (372.79), plastic products (250.98), and footwear (157). The highest EPRs in 1983 were provided to the leather and fur products (779.91), alcoholic beverages (623.82), and slaughtering and meat preservation (364.66) sectors. In the same year, the sectors receiving the lowest NPRs were ginning (7.42), other transport equipment (14.62), and other metallic ore mining (15.74). Similarly, the sectors receiving the lowest EPRs were fruit and vegetable canning $(-1949.8)$, processed tobacco and products (-1841.2), and other food processing (-1159.9). Comparing the 1983 figures with the average figures for the period 1990-1, we note that NPRs have decreased in 44 sectors and increased in five. Among the five sectors for which the NPRs increased, the greatest increase occurred in the alcoholic and non-alcoholic beverages sectors. On the other hand, the greatest decrease in NPR occurred in processed tobacco and products, plastic products, and leather and fur products sectors. In the case of EPR, we note that during the period 1983-91, the protection rates have increased in 19, and decreased in 30 industries. The largest increase in EPR occurred in the sectors of clothing, fruit and vegetable canning, and processed tobacco and products, the largest decrease in EPR occurred in the sectors of leather and fur products, slaughtering and meat preservation, and textiles. By 1991, the sectors receiving the highest EPRs were alcoholic beverages (182.25), nonalcoholic beverages (151.70), and clothing (123.07); and the sectors receiving the highest NPRs were clothing (6106), non-alcoholic beverages (1001.5), and alcoholic beverages (382.3). During the same year, the sector of ginning (3.55), iron ore mining (3.55), and railroad equipment (3.55) were granted the lowest NPRs. Similarly, the lowest EPRs were provided to the sectors of ginning $(-2.55)$, railroad equipment (3.94), and iron ore mining (10.55).

Ordering the sectors according to their EPR figures for the years 1990 and 1991, we note that among the first ten industries of the two orderings, the non-alcoholic beverages, alcoholic beverages, grain mill products, fruit and vegetable canning, processed tobacco and products, wood and cork products, sugar refining and plastic products sectors appear in both listings. Hence, these are the most protected sectors in the Turkish economy. The data further reveal that for sectors for which the EPR is less than zero but larger than $-100(-100<$ EPR $<0)$ the value added at the official exchange rate is less than the value added of its foreign counterparts. As such, these industries represent the least protected sectors in the economy. The numbers of such sectors were 
two in 1983, 1984 and 1988, zero in 1990 and one in 1991. From Table 2.10 it follows that the ginning sector has consistently been the least protected industry in the economy. Table 2.4 presents NPRs and EPRs for broad industry groups. In the upper part of this table, industries are classified into nine industry groups and in the lower part into four trade categories: export, export- and import-competing, importcompeting, non-import-competing. The classification of the sectors into four trade categories follows the rule adopted in Balassa et al. (1982).

Calculations presented in the first part of Table 2.4 reveal significant characteristics of the tariff system. There is a marked tendency for tariff rates to escalate from lower to higher stages of fabrication. In general, the tariff rates are lowest for primary activities, followed by mining and energy, and highest for manufacturing. For instance, in 1990 the NPR (EPR) was 10.86 (16.5) per cent for primary activities, 18.27 (29.27) per cent for mining and energy, and 36.23 (53.09) per cent for manufacturing. The escalation of subsidy rates is also evident among the subsectors of manufacturing, within which the lowest protection rates apply to intermediate goods and higher rates to consumer and investment goods. For instance, in 1990 the NPR was 25.87 per cent on intermediate goods, 37.87 per cent on investment goods and 52.34 per cent on consumer goods. During the same year the EPR was 23.29 per cent on intermediate goods, 56.97 per cent on consumer goods, and 68.17 on investment goods.

The second part of Table 2.4 reveals that, throughout the $1980 \mathrm{~s}$, the protection rates on export industries were higher than those on exportand import-competing, and non-import-competing industries. This indicates that Turkey's recent success in expanding its exports has been achieved under protection. The government protected the export industries, as evidenced by the high values of EPR in export industries compared to those in other industries.

\subsection{Export regime}

Since the adoption of the first five-year development plan in 1963, Turkey has encouraged economic activity through a complex system of incentives. Domestic investments were encouraged through investment allowances, tax deductions, low-cost credits and tariff reductions, and exemptions on imported machinery and material inputs. Until 1980 , domestic production was further assisted through import licensing, quantitative restrictions on imports and over-valued exchange rates. These measure discouraged exports by raising the profitability of 


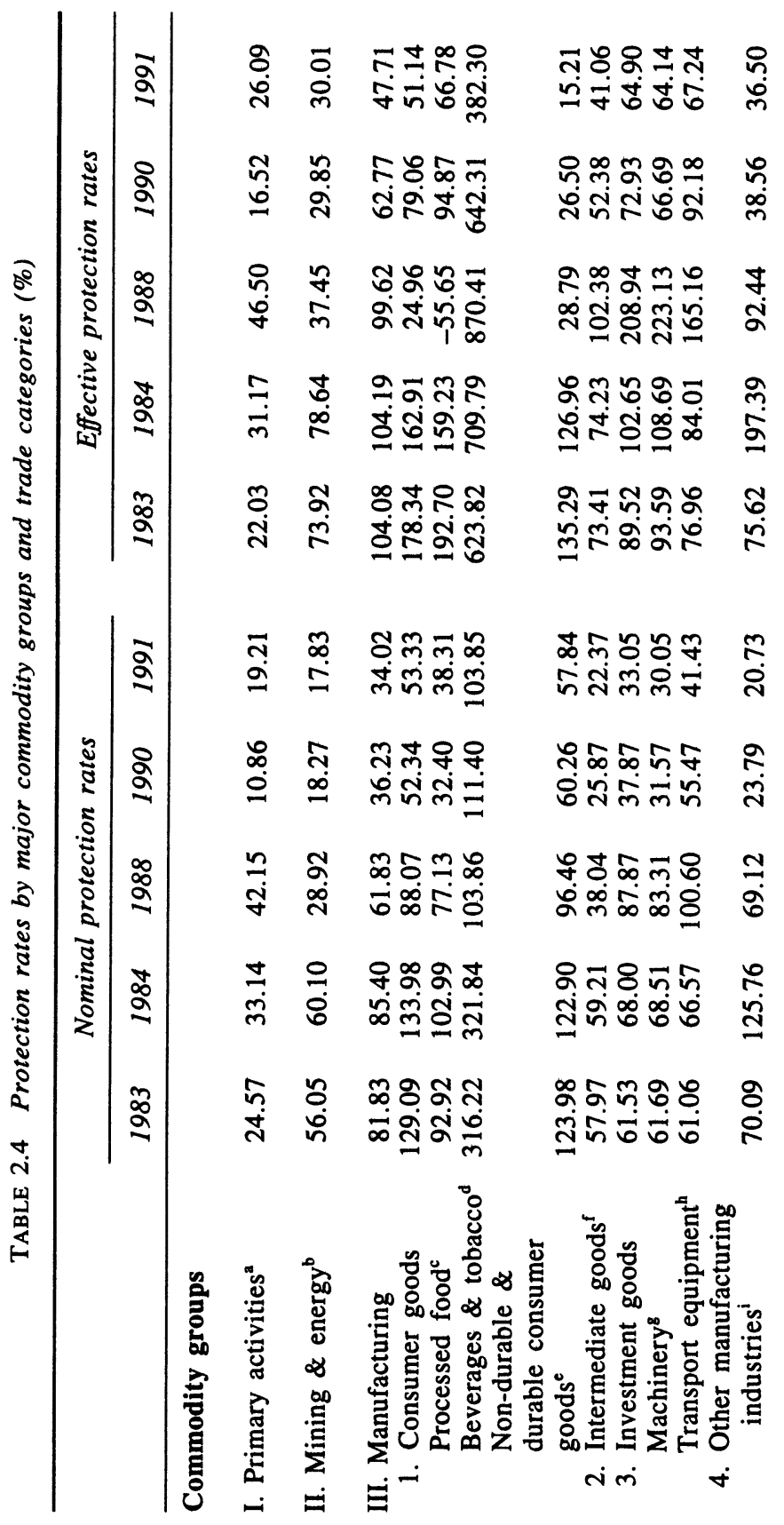




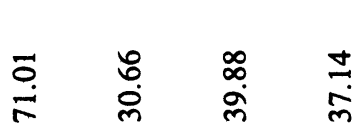

芯

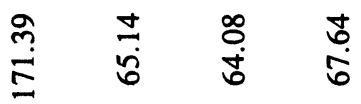

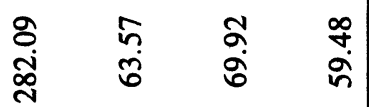

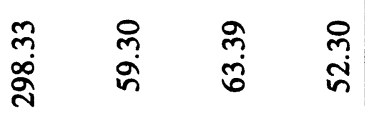

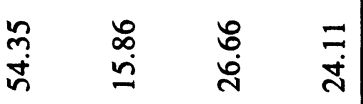

荧 ป⿱艹

ठू.

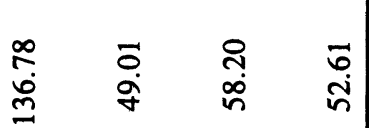

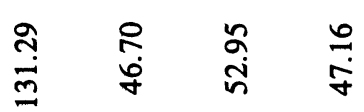

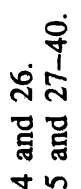

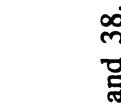

$\dot{q}+\frac{d}{d}$

再

สำ

竞 $+$

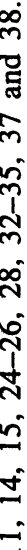

तल कलज

+อง

造

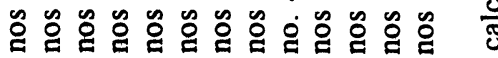

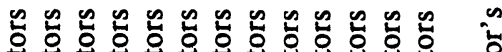

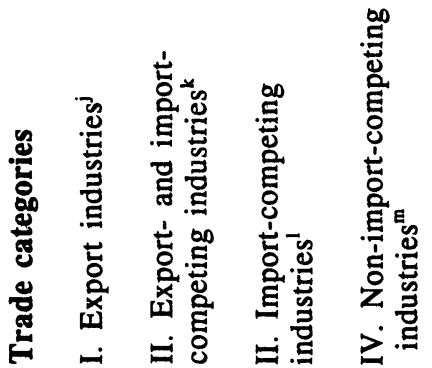

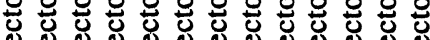

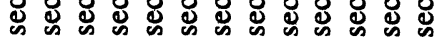

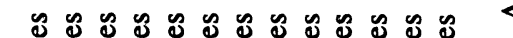

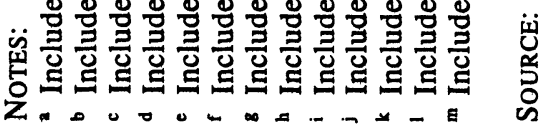


production for domestic markets over foreign markets. To counteract these adverse effects, incentives were provided to exports. Exports were encouraged through tax rebates, preferential credits, and tariff exemptions on imported inputs and packaging materials. However, these incentives were not sufficient enough to eliminate the then prevailing bias against exports.

In 1979, Turkey ran up against the limits of foreign borrowing and was forced to reschedule its debts to Western governments and foreign commercial banks. A precondition for rescheduling was the acceptance of the IMFs structural adjustment programme implemented on 24 January 1980. By 1985, Turkey's current account deficit was a manageable $\$ 1$ billion. The balance of payments turnaround during the 1980s was achieved largely by dramatic improvements in exports. Exports increased from $\$ 2.9$ billion in 1980 to $\$ 13.6$ billion in 1991 . The increase in exports experienced during the 1980s was achieved through a consistent export-promotion policy, which relied on three main instruments: exchange rate policy, which affects every tradeable good, and credit policy and fiscal incentives, both of which tend to produce biased sectoral effects.

In January of 1980, the Turkish lira (TL) was devalued by almost 50 per cent, from TL 47.10 to TL 70 per dollar. The then existent multiple exchange-rate system was eliminated except for import of fertilizers, and fertilizer inputs. After May 1981, the exchange rate was adjusted daily against major currencies in order to maintain the competitiveness of Turkish exports. In August 1988, a major reform was introduced and a system of market-setting of foreign exchange rates was adopted. The real depreciation of the Turkish lira, achieved through the exchange-rate policy followed during that period, provided a great incentive to Turkish exporters. Besides the exchange-rate policy, the government also relied on credit policy and fiscal incentives.

The government extended credit at preferential rates of interest to producers/exporters of selected products. During the first half of the 1980 s, a substantial difference existed between the general lending rate and the rate of interest applied to export credits. However, that system was abrogated in 1985. After 1987, preferential credits to exporters were extended via the newly established Eximbank.

The fiscal incentives provided to exporters during the 1980s included: export rate rebates; cash grants financed by the 'Support and Price Stabilization Fund'; duty-free imports of intermediates and raw materials; exemption from the production tax, which was replaced later by exemption from value added tax; foreign exchange allocations; 
exemption from corporate income tax; rebates from the 'Resource Utilization Support Fund'; exemption from various taxes related to alternative export transactions, and exemptions from freight rates. In addition to these subsidies, the exports of certain agricultural commodities were and still are subject to tax.

Table 2.5 shows the subsidy rates for each of the 49 tradeable sectors. From the table it follows that the economy-wide nominal subsidy rate declined over the period from 31.98 per cent in 1983 to 13.04 per cent in 1990. More significantly, recent policies have narrowed the inter-industry distribution of nominal subsidy rates. The standard deviation of nominal subsidy rates declined from 19.76 in 1983 to 8.13 in 1990.

The most striking conclusion to be derived from Table 2.5 relates to the level dispersion of subsidies in Turkey. From the table we note that amongst the 49 tradeable goods industries considered, there were eight industries in 1983, one in 1984 and 1986, and no industries in 1988 and 1990, which had nominal subsidy rates higher than 50 per cent. Additionally, there were ten industries in 1983, 15 in 1984, 23 in 1986, 17 in 1988, and 39 industries in 1990 which had a non-negative nominal subsidy rate less than 20 per cent. In 1986 there was one industry, in 1988 two industries and in 1990 three industries with negative subsidy rates.

After having discussed the level of subsidy, we now turn to a more detailed examination of the characteristics of export incentive policies. First, we note that in 1983 the highest subsidy rates were granted to the sectors of fabricated metal products (101.055), printing and publishing (73.364), and paper and paper products (73.226). In the same year, the sectors receiving the lowest subsidies were ginning (3.618), processed tobacco (7.439), and agriculture (7.713).

In 1984, the subsidy rates were reduced over all sectors. The highest reductions in subsidy rates were achieved in fabricated metal products, wood and cork products, wood furniture and fixtures. Comparison of the nominal subsidy rates for 1986 with those for 1984 reveals that subsidy rates were raised in four sectors and were reduced in the remaining 45 sectors. The sectors for which the nominal subsidy rates were increased included leather and fur products, processed tobacco, and ginning. In contrast, the largest reductions in subsidy rates during 1986 were achieved in the sectors of fabricated metal products, clothing, and other food processing. During the period 1986-8, subsidy rates increased in 27 sectors, and decreased in 22 sectors. The sectors for which the subsidy rates increased during the period included the grain 


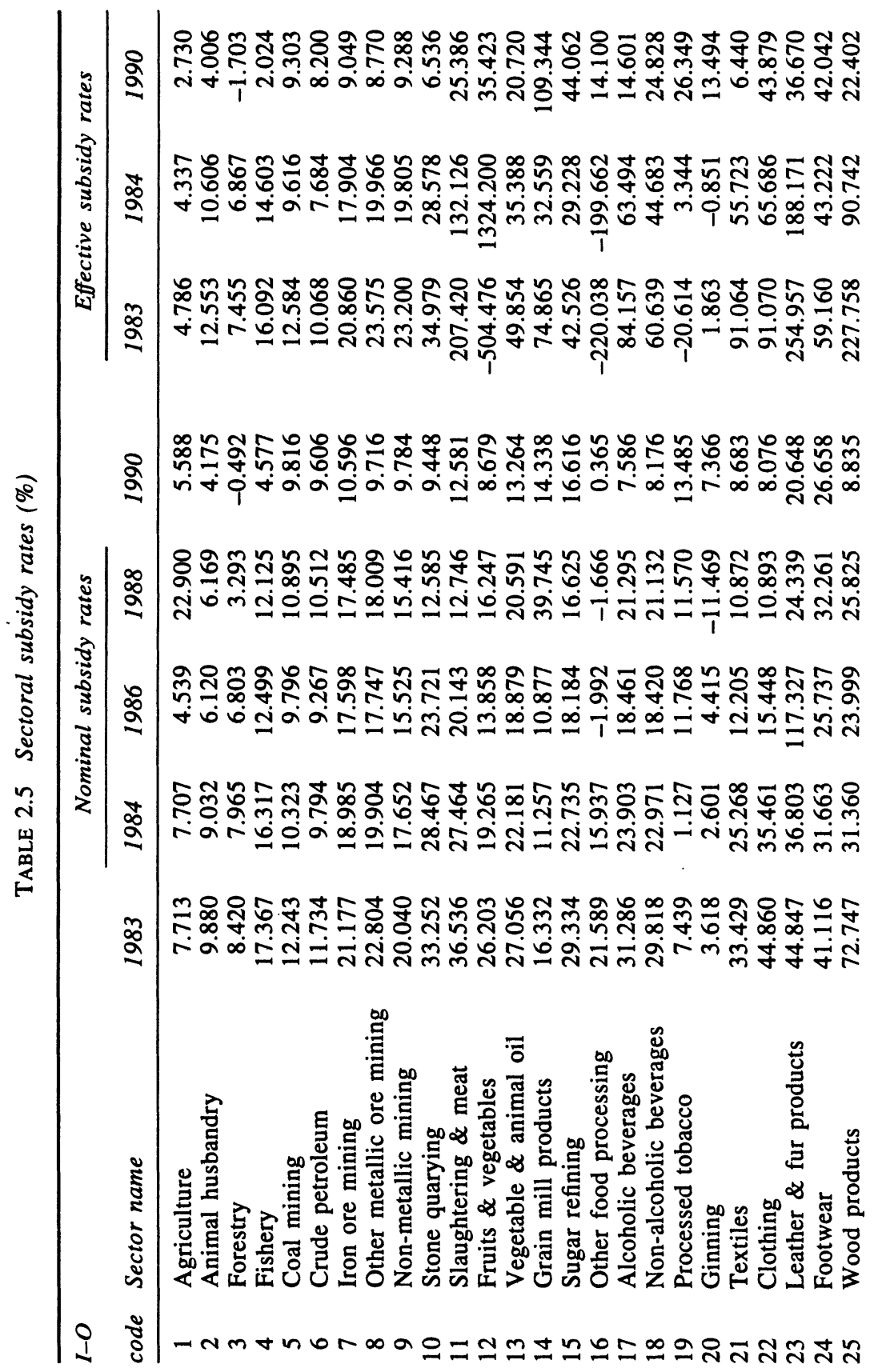




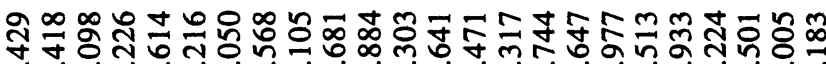

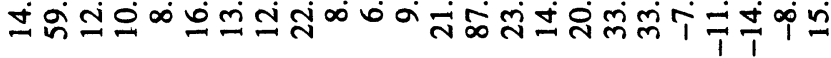

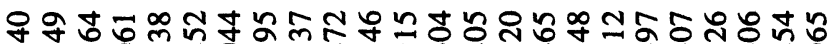

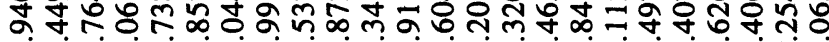

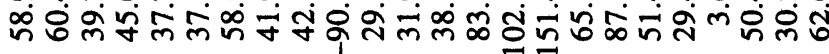

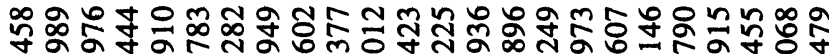

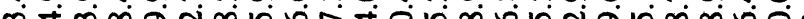

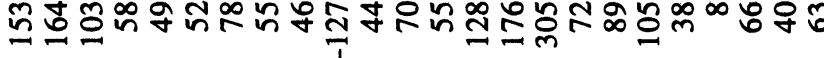

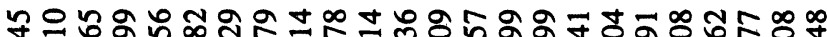

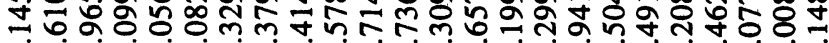

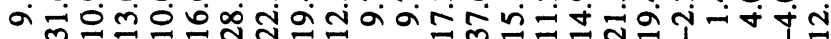

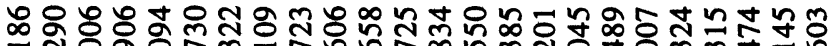

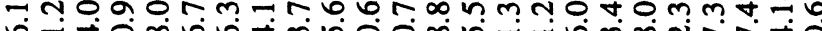

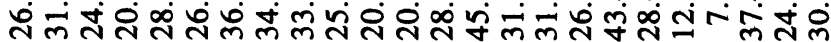
ஃ

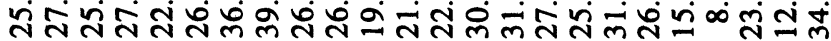

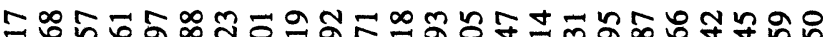

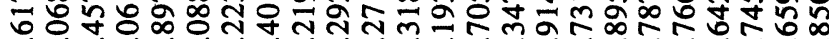

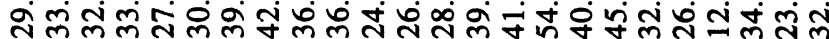

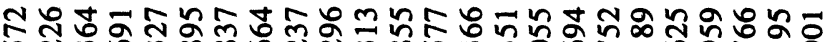
ก สุ

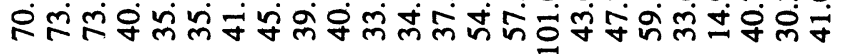

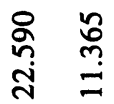

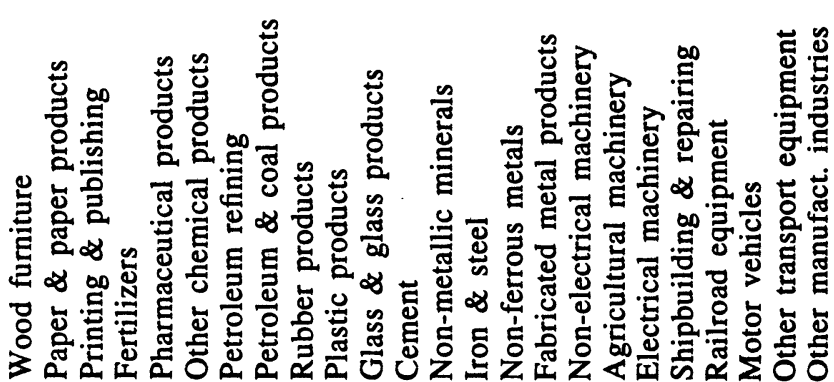

$\underset{\infty}{\infty} \stackrel{5}{+}$

$\stackrel{n}{ \pm}$

๙

m

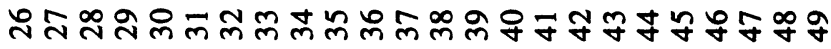


mill products, agriculture, and iron and steel industries. The sectors for which subsidy rates decreased included leather and fur products, ginning, and stone quarrying industries. During the period 1988-90, subsidy rates increased in four and decreased in 45 industries. The sectors for which subsidy rates increased included ginning, other food processing, and processed tobacco. The sectors for which subsidy rates decreased included motor vehicles, other transport equipment, and grain mill products. By 1990 , the highest subsidy rates were paid to iron and steel (37.657), paper and paper products (31.61), and petroleum refinery (28.329). On the other hand, the sectors of other transport equipment $(-4.008)$, shipbuilding and repairing $(-2.208)$, and forestry $(-0.492)$ received the lowest subsidy rates.

Table 2.6 present nominal subsidy rates for broad industry groups. In the upper part of the table industries were classified into nine industry groups, and in the lower part into four trade categories. Calculations presented in the first part of Table 2.6 reveal significant characteristics within the subsidy system. There is a marked tendency for subsidy rates to escalate from lower to higher stages of fabrication. In general, the subsidy rates are lowest for primary activities, followed by mining and energy, and highest for manufacturing. For instance, in 1984 the nominal subsidy rate was 8.31 per cent for primary activities, 15.43 per cent for mining and energy, and 31.64 per cent for manufacturing. The escalation of subsidy rates is also evident among the subsectors of manufacturing, within which the lowest subsidy rates apply to consumer goods. Higher rates were applied during the 1980s to investment goods and in 1990 to intermediate goods.

The second part of Table 2.6 reveals that, throughout the 1980s, the subsidy rates on export industries were lower than those on exportand import-competing industries, which, in turn, received the highest subsidy rates among the four trade categories.

Nominal subsidy is concerned with the impact of incentives on product prices. Effective subsidy (ESR) is concerned with the impact of incentives on production activities, taking into account incentives to outputs and tariffs and tariff-like charges to the intermediate inputs of these activities. Calculations of the ESR for 1983 and 1990 in Table 2.6 reveal that the average ESR for the economy as a whole decreased from 37.52 in 1983 to 12.25 in 1990 . Furthermore, the inter-industry distribution of effective subsidy rates narrowed during the period. The standard deviation of effective subsidy rates declined from 115.861 in 1983 to 22.513 in 1990.

Consideration of the frequency distribution of ESRs reveals that 
among the 49 tradeable sectors considered there were 10 (1) industries in 1983 (1990) which had an effective subsidy rate higher than 100 per cent. There were 16 (2) industries in 1983 (1990) with effective subsidy rates within the range of 20-50, and 8 (24) industries in the range of $0-20$. in 1983 (1990) there was 1 (6) industry with negative effective subsidy rates with values greater than -100 , and there were 3 (0) industries with effective subsidy rates less than -100 .

In 1983, the sectors with the highest effective subsidy rates were fabricated metal products (305.249), leather and fur products (254.957) and wood products (227.758) industries. The sectors with the lowest effective subsidy rates were fruits and vegetables $(-504.476)$, other food processing (-200.038), and plastic products $(-127.377)$. In 1990, the sectors with the highest effective subsidy rates included the grain mill products (109.344), iron and steel (87.471), and agricultural machinery (59.418) industries. The sectors with the lowest effective subsidy rates were motor vehicles $(-14.501)$, other food processing $(-14.1)$, and railroad equipment $(-11.224)$.

During the period 1983-4, effective subsidy rates increased in four and decreased in 45 industries. The largest increase in effective subsidy rates occurred in the sectors of fruits and vegetables, plastic products, and processed tobacco. The largest decreases in effective subsidy rates were achieved in the fabricated metal products, wood products, and paper and paper products industries. During the 1984-90 period, effective subsidy rates increased in eight, and decreased in 41 industries. The largest increases in effective subsidy rates were achieved in the sectors of other food processing, plastic products, and grain mill products. Effective subsidy rates decreased in the fruits and vegetables, leather and fur products, and fabricated metal products industries.

Table 2.6 present the effective subsidy rates for the broad industry groups introduced in Table 2.4. From the table we note that effective subsidy rates escalate from lower to higher stages of fabrication. The effective subsidy rates are lowest for primary activities, followed by mining and energy, and highest on manufacturing. In 1983 (1990) the effective subsidy rate was 6.38 (2.55) per cent for primary activities, 17.63 (8.64) per cent for mining and energy, and 77.80 (23.26) per cent for manufacturing. The second part of Table 2.6 reveals that in 1983 (1990) the highest effective subsidy rates applied to export- and import-competing industries, as in the case of nominal subsidy rates. 


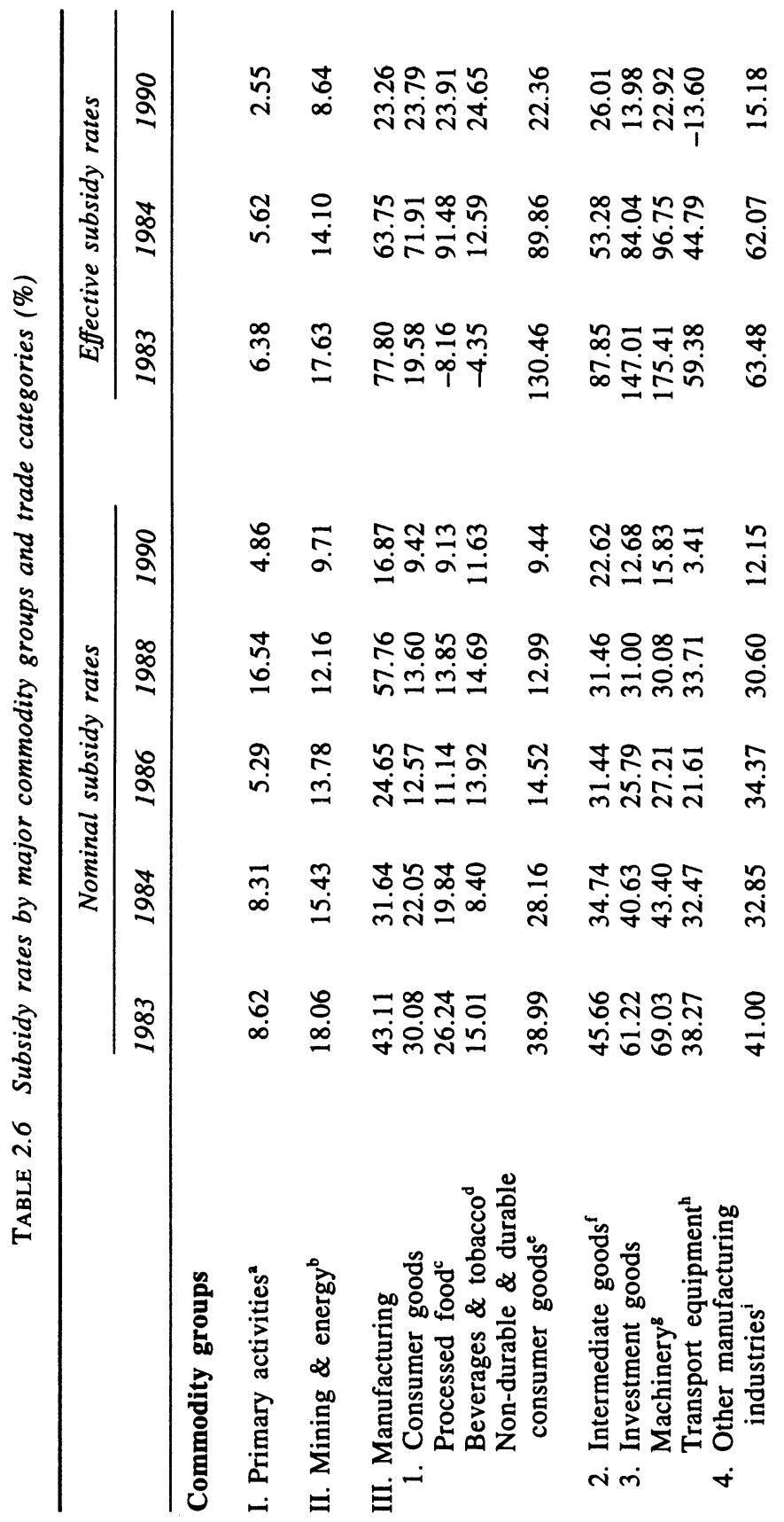




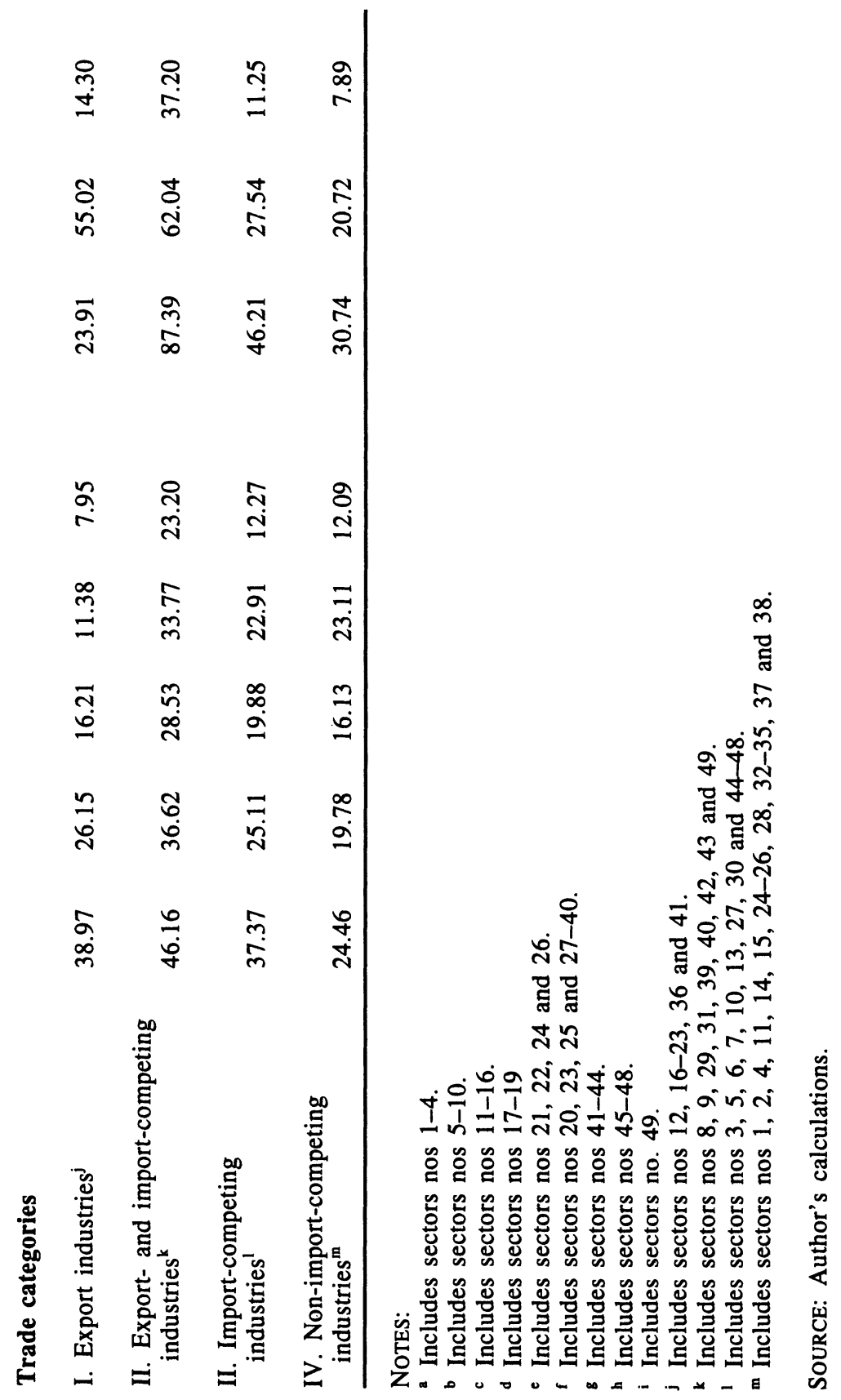




\subsection{Real exchange rate}

Towards the end of the 1970s, Turkey followed a fixed and multiple exchange-rate policy. With the stabilization measures of 1980, Turkey devalued the Turkish lira (TL) by almost 50 per cent. The multiple exchange-rate system was eliminated except for imports of fertilizers, and fertilizer inputs. After May 1981, the exchange rate was adjusted daily against major currencies in order to maintain the competitiveness of Turkish exports. In August 1988, major reform was introduced, and a system of market setting of foreign exchange rates was adopted.

The success of liberalization policies depends in the long term on developments of the real exchange rate. The appreciation of the real exchange rate contributes in the long run to expansion and the depreciation to reduction of the trade deficit.

From Table 2.7 we note that the real exchange rate is defined as

$$
\emptyset=\left(E p^{\$} / p\right)
$$

where $E$ denotes the exchange rate, the price of foreign currency in terms of Turkish lira, $p^{\$}$ is the foreign price index measured by the GDP price deflator, and $p$ is the domestic price index measured by GDP price deflator. The real exchange rate appreciated considerably during the 1970s, leading to the balance-of-payments problems of the late 1970s. During the 1980s, the real exchange rate depreciated until 1988 , contributing to a large increase in exports. Thereafter, the trend in the real exchange rate was reversed.

\subsection{Anti-export bias and sectoral real effective exchange rates}

A natural question that arises is whether the expanded export incentives and the tariff reductions analyzed above have reduced the bias against exports entailed by import-protection and export-promotion measures. This question may be answered by calculating the profitability of producing for export relative to domestic market, approximated using the measure

$$
\pi=(1+s) /(1+t),
$$

where $s$ denotes the subsidy rate and $t$ the protection rate. In the following, we consider for the subsidy rates the nominal and effective subsidy, and for the protection rates the nominal and effective protection rates. 
Table 2.8 presents the anti-export bias figures for the 49 tradeable sectors evaluated using the figures given in Tables 2.3 and 2.5. From the table it follows that, on average, anti-export bias prevailed during the 1980s. The average value of anti-export bias evaluated using nominal figures was 0.864 in $1983,0.792$ in $1984,0.83$ in 1988, and 0.914 in 1990. The average value of anti-export bias evaluated using effective figures was 0.896 in 1983, 0.79 in 1984, and 0.84 in 1990. The figures indicate anti-export bias, since the average figures for the economy as a whole are less than unity throughout this period. The average value of anti-export bias continues to increase over time. This development clearly represents changes in a healthy direction. Since, under a liberal trade regime, the measure of anti-export bias would equal unity and variance zero, we note that there still remains an area for considerable improvement.

Consideration of sectoral anti-export measures using nominal subsidy and protection figures reveals that in 1983, 12 industries had $\pi$ values greater than unity (indicating export bias), and 37 sectors had $\pi$ values less than unity (indicating anti-export bias). During 1983, the highest $\pi$ figures applied to the printing and publishing (1.375), other transport equipment (1.138), and iron and steel (1.106) sectors; and the lowest figures to the processed tobacco and products $(0.524)$, plastic products $(0.4)$, and fruit and vegetables canning (0.524) sectors. By 1990 , the ordering had changed and 11 industries had $\pi$ values greater than unity, while 38 industries had $\pi$ values less than unity. During 1990 , the highest $\pi$ figures applied to the iron and steel (1.254), iron ore mining (1.06), and other metallic ore mining (1.05) sectors. The alcoholic beverages $(0.324)$, non-alcoholic beverages $(0.429)$, and clothing $(0.487)$ sectors were receiving the lowest $\pi$ figures. The trade policies that were followed during the period 1983-90 resulted in considerable increases in the $\pi$ values of the leather and fur products, processed tobacco and products, and plastic products sectors, and in decreases in $\pi$ values of the printing and publishing, and alcoholic and non-alcoholic beverages sectors.

Consideration of sectoral anti-export measures using effective subsidy and protection figures reveals that in 1983, 18 industries had $\pi$ values greater that unity (indicating export bias), and 31 sectors had $\pi$ values less than unity (indicating anti-export bias). During 1983, the highest $\pi$ figures applied to the printing and publishing (1.837), sugar refining (1.815), and fabricated metal products (1.562) sectors; and the lowest figures to the processed tobacco and products $(-0.046)$, plastic products $(0.035)$, and other food processing $(0.113)$ sectors. By 


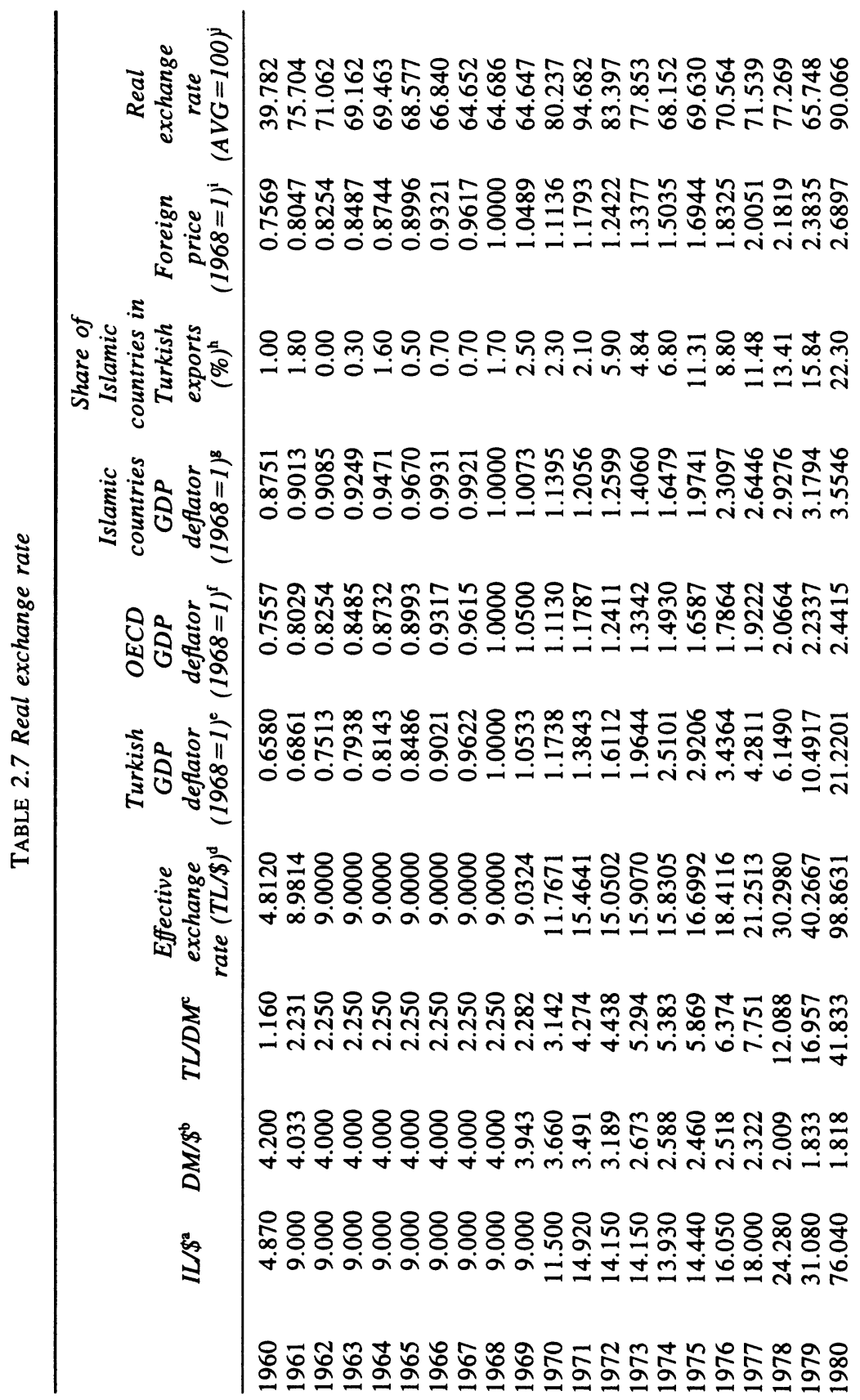




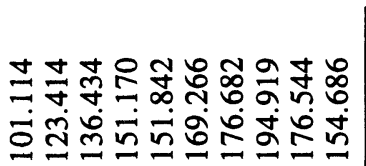

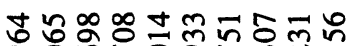

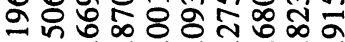

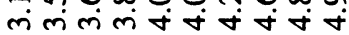

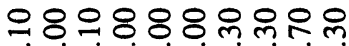

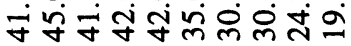

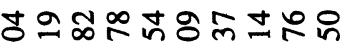

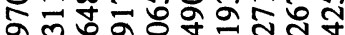

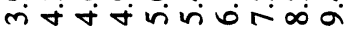

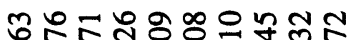
นัญ。

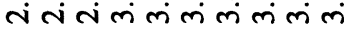

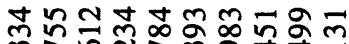

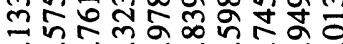

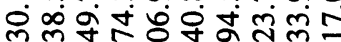

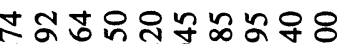
तु तi mंio $\infty$ via

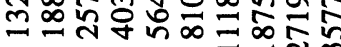

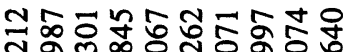

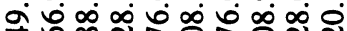

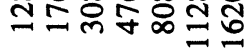

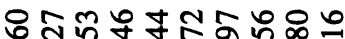

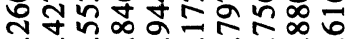
तnindi-i-

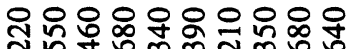

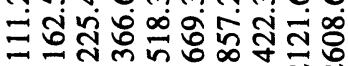

దే ఋ $\infty$
喾

I

葛

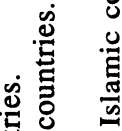

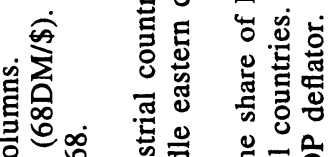

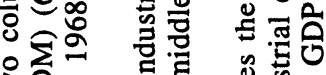

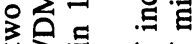

州

幽䨔

도

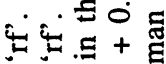

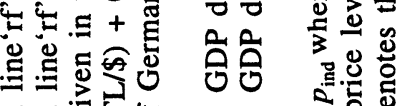

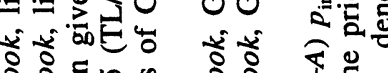

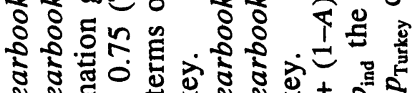
ข

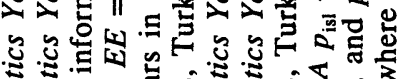

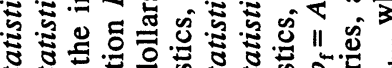
๘ं山 .

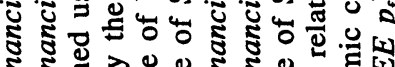

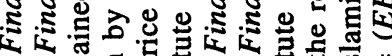

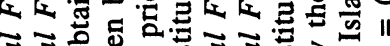
సี

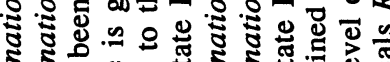
ह

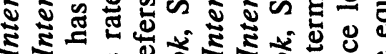
Ч

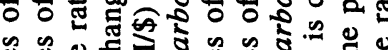
ఖ \& ๙

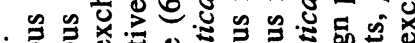

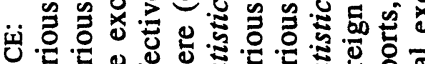

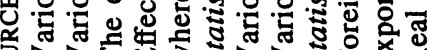

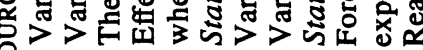




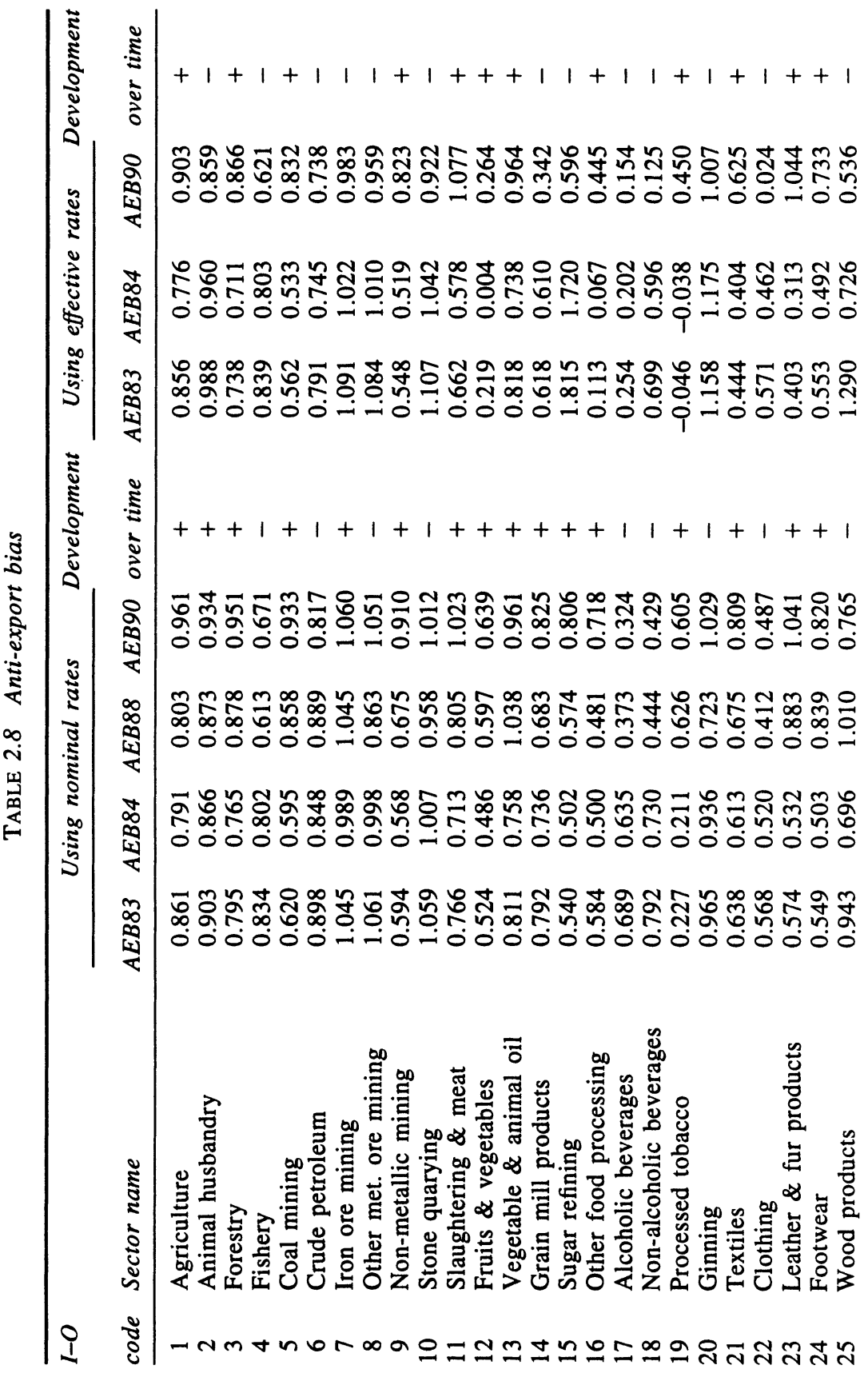


$1+1111+t+1+111+111111111+$

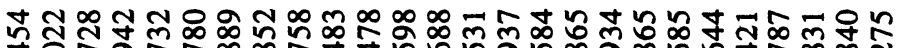

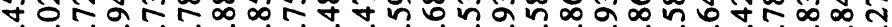
$0-00000000000-000000000000$

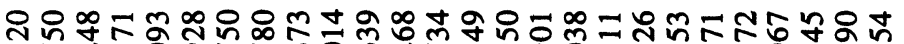
nर $00-1000000-0.001-0000-000$

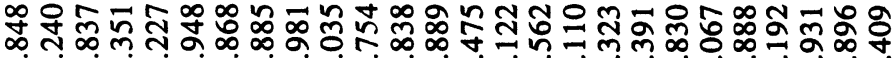

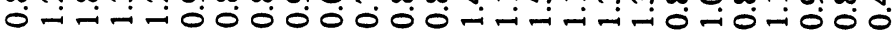

$1+1111+t+1+111++111111111+$

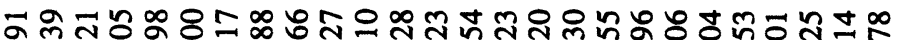

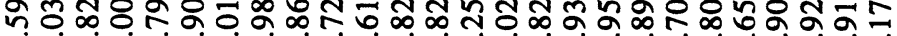
$0-0-i 00-10000001-100000000000$

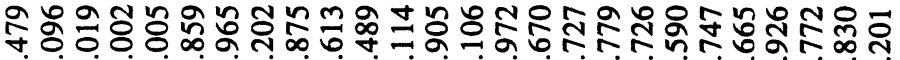
$0-i-100-000-10-1000000000000$

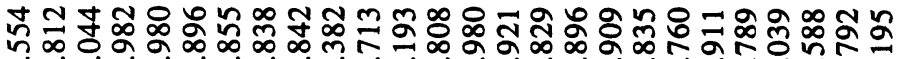

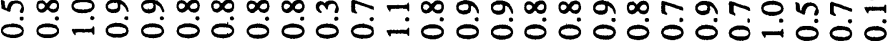

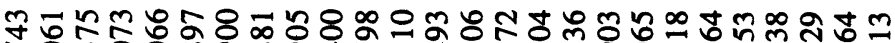

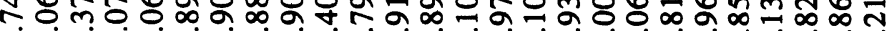

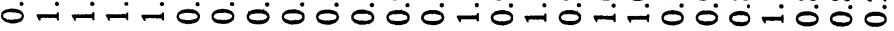

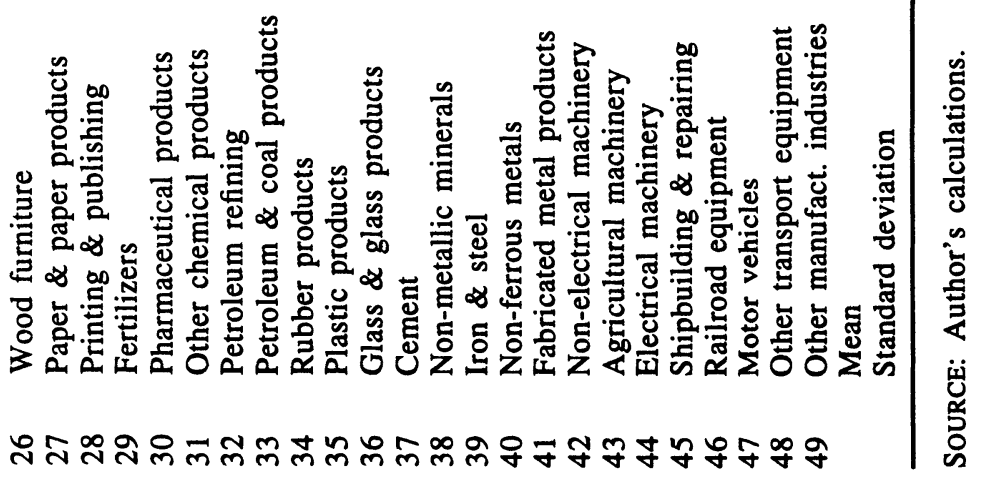


1990 , the ordering had changed and five industries had $\pi$ values greater than unity, while 44 industries had $\pi$ values less than unity. During 1990 , the highest $\pi$ figures applied to the iron and steel (1.531), slaughtering and meat (1.077), and leather and fur products (1.044) sectors. The clothing (0.024), non-alcoholic beverages $(0.125)$, and alcoholic beverages $(0.154)$ sectors were receiving the lowest $\pi$ figures.

In Table 2.8, the columns showing the development of $\pi$ values over time have been obtained by regressing the $\pi$ value on time $(t)$

$$
\pi=\alpha+\beta t
$$

In the table, the sectors for which $\beta$ is positive (negative) are shown with a '+' ('-') sign. The table indicates that when anti-export bias is estimated by using nominal effective subsidy and protection rates, anti-export bias has been decreasing for 23 (18) sectors and increasing for 26 (31) sectors. For the economy as a whole, anti-export bias has been decreasing (constant) over time.

Table 2.9 shows the sectoral profitabilities of producing for exporting relative to home production, measured by he relation $v_{i}=\left(E p_{i}^{\$}\right.$ $\left(1+s_{i}\right) / p$ ) where $s_{i}$ denotes the nominal subsidy rate of sector $i$. From the table, it follows that the economy-wide $v$ increased over the period 1983-8, but decreased substantially over 1988-90. Thus, the incentives provided to production of exportables relative to domestic production decreased substantially over the period 1988-90.

\section{COMPARATIVE ADVANTAGE}

It has been shown by various economists that free trade policy is the optimal policy for a small country in the world economy. Under free trade, the country will produce and export (import) the commodities in which it has comparative advantage (disadvantage). Theoretically, comparative advantage can be determined by comparing the autarkic equilibrium price vector with the free trade price vector. But difficulties are encountered when trying to evaluate the autarkic equilibrium price vector empirically. For the determination of the sectors with comparative advantage, we first consider domestic resource costs and then revealed comparative advantage. As is well known, empirical measures of comparative advantage can help to identify the overall direction and thrust which a country's investment and trade should take in order to exploit international differences in product and factor supply and demand. 
TABLE 2.9 Sectoral real effective exchange rates

\begin{tabular}{|c|c|c|c|c|c|c|}
\hline $\begin{array}{l}I-O \\
\text { code }\end{array}$ & Sector name & 1983 & 1984 & 1986 & 1988 & 1990 \\
\hline 1 & Agriculture & 1.000 & 1.050 & 1.079 & 1.278 & 0.830 \\
\hline 2 & Animal husbandry & 1.000 & 1.042 & 1.074 & 1.082 & 0.802 \\
\hline 3 & Forestry & 1.000 & 1.046 & 1.096 & 1.067 & 0.777 \\
\hline 4 & Fishery & 1.000 & 1.041 & 1.066 & 1.070 & 0.754 \\
\hline 5 & Coal mining & 1.000 & 1.033 & 1.088 & 1.107 & 0.828 \\
\hline 6 & Crude petroleum & 1.000 & 1.032 & 1.088 & 1.108 & 0.830 \\
\hline 7 & Iron ore mining & 1.000 & 1.031 & 1.079 & 1.086 & 0.773 \\
\hline 8 & Other metallic ore mining & 1.000 & 1.026 & 1.066 & 1.076 & 0.756 \\
\hline 9 & Non-metallic mining & 1.000 & 1.030 & 1.070 & 1.077 & 0.774 \\
\hline 10 & Stone quarying & 1.000 & 1.013 & 1.033 & 0.946 & 0.695 \\
\hline 11 & Slaughtering \& meat & 1.000 & 0.981 & 0.979 & 0.925 & 0.698 \\
\hline 12 & Fruits \& vegetables & 1.000 & 0.993 & 1.003 & 1.032 & 0.729 \\
\hline 13 & Vegetable \& animal oil & 1.000 & 1.010 & 1.041 & 1.063 & 0.755 \\
\hline 14 & Grain mill products & 1.000 & 1.005 & 1.060 & 1.346 & 0.832 \\
\hline 15 & Sugar refining & 1.000 & 0.997 & 1.016 & 1.010 & 0.763 \\
\hline 16 & Other food processing & 1.000 & 1.002 & 0.897 & 0.906 & 0.699 \\
\hline 17 & Alcoholic beverages & 1.000 & 0.991 & 1.004 & 1.035 & 0.694 \\
\hline 18 & Non-alcoholic beverages & 1.000 & 0.995 & 1.015 & 1.045 & 0.705 \\
\hline 19 & Processed tobacco & 1.000 & 0.989 & 1.157 & 1.163 & 0.894 \\
\hline 20 & Ginning & 1.000 & 1.040 & 1.121 & 0.957 & 0.877 \\
\hline 21 & Textiles & 1.000 & 0.986 & 0.935 & 0.931 & 0.689 \\
\hline 22 & Clothing & 1.000 & 0.982 & 0.886 & 0.857 & 0.631 \\
\hline 23 & Leather \& fur products & 1.000 & 0.992 & 1.669 & 0.962 & 0.705 \\
\hline 24 & Footwear & 1.000 & 0.980 & 0.991 & 1.050 & 0.760 \\
\hline 25 & Wood products & 1.000 & 0.799 & 0.798 & 0.816 & 0.533 \\
\hline 26 & Wood furniture & 1.000 & 0.798 & 0.818 & 0.829 & 0.542 \\
\hline 27 & Paper \& paper products & 1.000 & 0.807 & 0.816 & 0.849 & 0.643 \\
\hline 28 & Printing \& publishing & 1.000 & 0.803 & 0.808 & 0.801 & 0.542 \\
\hline 29 & Fertilizers & 1.000 & 0.994 & 1.010 & 0.963 & 0.680 \\
\hline 30 & Pharmaceutical products & 1.000 & 0.993 & 1.008 & 1.060 & 0.688 \\
\hline 31 & Other chemical products & 1.000 & 1.006 & 1.039 & 1.045 & 0.723 \\
\hline 32 & Petroleum refining & 1.000 & 1.031 & 1.073 & 1.077 & 0.766 \\
\hline 33 & Petroleum \& coal products & 1.000 & 1.027 & 1.069 & 1.031 & 0.711 \\
\hline 34 & Rubber products & 1.000 & 1.028 & 1.008 & 1.076 & 0.726 \\
\hline 35 & Plastic products & 1.000 & 1.021 & 1.001 & 1.003 & 0.679 \\
\hline 36 & Glass \& glass products & 1.000 & 0.979 & 1.000 & 1.014 & 0.697 \\
\hline 37 & Cement & 1.000 & 0.984 & 1.005 & 1.003 & 0.689 \\
\hline 38 & Non-metallic minerals & 1.000 & 0.979 & 0.994 & 1.049 & 0.722 \\
\hline 39 & Iron \& steel & 1.000 & 0.951 & 0.938 & 1.056 & 0.755 \\
\hline 40 & Non-ferrous metals & 1.000 & 0.944 & 0.927 & 0.935 & 0.620 \\
\hline 41 & Fabricated metal products & 1.000 & 0.809 & 0.708 & 0.731 & 0.469 \\
\hline 42 & Non-electrical machinery & 1.000 & 1.029 & 0.970 & 0.983 & 0.677 \\
\hline
\end{tabular}


TABLE 2.9 continued

\begin{tabular}{lllllll}
\hline $\begin{array}{l}\text { I- } O \\
\text { code }\end{array}$ & \multicolumn{1}{c}{ Sector name } & 1983 & 1984 & 1986 & 1988 & 1990 \\
\hline 43 & Agricultural machinery & 1.000 & 1.037 & 0.987 & 1.088 & 0.696 \\
44 & Electrical machinery & 1.000 & 0.876 & 0.885 & 0.901 & 0.635 \\
45 & Shipbuilding \& repairing & 1.000 & 0.997 & 0.960 & 0.942 & 0.619 \\
46 & Railroad equipment & 1.000 & 1.029 & 1.048 & 1.046 & 0.747 \\
47 & Motor vehicles & 1.000 & 1.006 & 0.975 & 1.094 & 0.626 \\
48 & Other transport equipment & 1.000 & 0.996 & 0.957 & 1.066 & 0.623 \\
49 & Other manufact. industries & 1.000 & 0.990 & 1.060 & 1.038 & 0.673 \\
& & & & & & \\
Mean & 1.000 & 0.997 & 1.011 & 1.059 & 0.738 \\
\hline
\end{tabular}

SOURCE: Author's calculations.

\subsection{Domestic resources cost}

The concept of domestic resource cost was developed during the early 1960 s in Israel. It measures the resource cost of earning foreign exchange through exporting commodities or saving foreign exchange through import substitution. The concept is closely related to the concept of effective rate of protection. This relation can be shown using the measure of effective protection coefficient given by

$$
V A_{\mathrm{d}} / V A_{\mathrm{w}}
$$

where $V A_{\mathrm{d}}$ denoted valued added at domestic prices and $V A_{\mathrm{w}}$ value added at world prices. Since $V A_{\mathrm{w}}=E V A_{\mathrm{w}}^{\$}$, where $V A_{\mathrm{w}}^{\$}$ denotes value added at world prices measured in foreign currency and $E$ the exchange rate, we note that the effective protection coefficient is the same thing as the DRC ratio. Hence the DRC coefficient can be calculated as

$$
\left.\mathrm{DRC}=V A_{\mathrm{d}} / V A_{\mathrm{w}}^{\mathrm{s}}=(1+\mathrm{EPR} / 100)\right) E
$$

where EPR denote the effective protection rate.

The domestic resources cost (DRC) coefficients for the tradeable sectors are shown in Table 2.10. In the calculation of DRC coefficients, we used the average value of the exchange rate of $521.98 \mathrm{TL} / \$$ for the year 1985, the year in which the input-output table was prepared and the effective protection coefficients calculated by Togan (1993). The last column of Table 2.1 shows the development of the DRC coefficient 
over time. For that purpose, we regress the value of the DRC on time $(t)$.

$$
\mathrm{DRC}=\alpha+\beta t,
$$

and show the sectors for which $\beta$ is positive (negative) with a ' + ' ('-') sign. In Table 2.10 the sectors are divided into four cells. The top two cells contain sectors with decreasing DRC values over time and the lower two cells the sectors with increasing DRC values over time. The top (lower) two cells have been ordered according to their DRC values, and the dividing measure is the average value of DRC for the economy as a whole. The upper (lower) cell contains the sectors with lower (higher) DRC values than the average. The broad mix of goods appearing in the upper cell may be considered as the sectors having comparative advantage. By contrast, we can say that the sectors in the lower cell of Table 2.10 have comparative disadvantage according to the DRC criteria.

\subsection{Revealed comparative advantage}

It is generally recognized that the disaggregated exports of a country indicate where the domestic industries display international competitiveness, while a country's imports pinpoint where it lacks such competitiveness. Following Volrath (1991), we calculate the 'revealed comparative advantage' by the formula.

$$
\mathrm{RCA}_{i}=\ln \left[\left(X_{i} / X\right) /\left(X_{i}^{\mathrm{w}} / X^{\mathrm{w}}\right)\right]
$$

where $X_{i}$ denotes exports of commodity $i$ by the country, $X$ total exports of the country, $X_{i}^{\mathrm{w}}$ world exports of commodity $i$ excluding the exports of the country, $X^{w}$ world exports excluding the exports of the country, and ' $I n$ ' the natural logarithm of the variable.

In this study, the RCA indexes were calculated for two digit SITC classification of trade data over the period 1980-8. Turkey's leading export industries are those in the uppermost cell of Table 2.11 - products with high and rising RCAs. A broad mix of goods appear in this cell. By contrast, the lowest cell of Table 2.11 lists products with low and falling RCAs, hence commodities with comparative disadvantage according to RCA criteria. Weak but improving export positions are evident in the cell 'low and rising RCA', which contains commodities with increasing but with negative RCA values greater than -1 . In the following, we call the sectors which have RCA values greater than -1 
TABLE 2.10 Comparative advantage according to domestic resource cost (DRC)

\begin{tabular}{lcc}
\hline$-O$ & $D R C$ \\
code & Sector name & $1990-1$ \\
\hline
\end{tabular}

\section{Low and falling}

7 Iron ore mining

578.0929

8 Other met. ore mining

590.4377

3 Forestry

599.5201

10 Stone quarying

601.8690

48 Other transport equipment

602.0778

29 Fertilizers

610.2207

13 Vegetable \& animal oil

619.0422

Agriculture

633.5010

39 Iron \& steel

33 Petroleum \& coal products

639.2428

640.5478

32 Petroleum refining

11 Slaughtering \& meat

663.6454

671.4751

23 Leather \& fur products

675.2594

5 Coal mining

683.4023

40 Non-ferrous metals

49 Other man. industries

684.1070

717.8791

42 Non-electrical machinery

718.7404

9 Non-metallic mining

729.1017

43 Agricultural machinery

738.9671

31 Other chemical products

762.2996

\section{High and falling}

27 Paper \& paper products

809.3822

45 Shipbuilding \& repairing

820.2916

21 Textiles

38 Non-metallic minerals

884.1036

37 Cement

886.0089

47 Motor vehicles

900.5199

990.7963

24 Footwear

993.3540

36 Glass \& glass products

1000.2964

41 Fabricated metal products

1012.4324

26 Wood furniture

1098.0632

25 Wood products

1141.7269

12 Fruits \& vegetables

2240.5209

17 Alcoholic beverages

Low and rising

20 Ginning

2 Animal husbandry

46 Railroad equipment 
28 Printing \& publishing

707.1002

6 Crude petroleum

756.7405

30 Pharmaceutical products

764.3614

\section{High and rising}

44 Electrical machinery

810.8176

34 Rubber products

839.5526

4 Fishery

856.8302

16 Other food processing

1046.9353

35 Plastic products

1152.6623

15 Sugar refining

1166.2077

19 Processed tobacco

1405.0136

14 Grain mill products

2541.0

SOURCE: Author's calculations.

TABLE 2.11 Comparative advantage according to the values of revealed comparative advantage

\begin{tabular}{ll}
\hline SITC & $1989-90$ \\
\hline
\end{tabular}

High and rising RCA

57 Explosives

52 Inorganic chemicals

84 Clothing

42 Fixed vegetable oils and fats

67 Iron and steel

09 Animal oils and fats

56 Fertilizers, manufactured

55 Essential oils and perfume materials

83 Travel goods

43 Animal and vegetable oils and fats, proc.

81 Sanitary, plumbing, heating

41 Animal oils and fats

07 Miscellaneous edible products

28 Metalliferous ores and metal scrap
3.0118

2.7275

2.0696

1.1894

1.1450

0.8408

0.6109

0.4640

0.3333

0.1363

0.0954

0.0906

0.0680

0.0662

\section{Medium and rising RCA}

68 Non-ferrous metals

$-0.1639$

62 Rubber manufactures

$-0.1688$

54 Medicinal and pharmaceutical products

$-0.4432$

69 Manufactures of metal

$-0.6177$

51 Organic chemicals

$-0.7472$

85 Footwear

$-0.8179$

33 Petroleum and petroleum products

$-0.8421$ 
TABLE 2.11 continued

\begin{tabular}{|c|c|c|}
\hline \multicolumn{2}{|c|}{ SITC } & $1989-90$ \\
\hline \multicolumn{3}{|c|}{ Low and rising RCA } \\
\hline 53 & Dyeing, tanning, and colouring materials & -1.0306 \\
\hline 72 & Electrical machinery & -1.1781 \\
\hline 64 & Paper & -1.5627 \\
\hline 59 & Chemical materials and products & -1.7483 \\
\hline 23 & Crude rubber & -1.7498 \\
\hline 61 & Leather manufactures & -1.8614 \\
\hline 08 & Feeding stuff for animals & -2.1977 \\
\hline 71 & Machinery, other than electric & -2.2259 \\
\hline 58 & Plastic materials & -2.3168 \\
\hline 86 & Scientific instruments and optical goods & -3.4336 \\
\hline
\end{tabular}

\section{High and falling RCA}

05 Vegetables and sugar preparations

2.1225

12 Tobacco

00 Live animals chiefly for food

27 Crude fertilizers and crude minerals

65 Textiles

1.2806

26 Textile fibres and their wastes

1.1097

29 Crude animal and vegetable materials

0.4641

66 Non-metallic mineral manufactures

0.1273

\section{Medium and falling RCA}

04 Cereals and cereal preparations

$-0.5363$

03 Fish and fish preparations

$-0.5625$

06 Coffee, tea, cocoa, spices

$-0.5656$

\section{Low and falling RCA}

63 Wood manufactures

01 Meat and meat preparations

$-1.5015$

24 Cork and wood

$-1.5302$

82 Furniture

$-1.6937$

22 Oil seeds and oleaginous fruit

$-1.6987$

89 Miscellaneous manufactured articles

$-1.7888$

11 Beverages

$-1.8514$

02 Dairy products

$-1.8658$

73 Transport equipment

$-1.9274$

21 Hides, skins and fur-skins, raw

$-2.2525$

32 Coal

$-3.8368$

25 Pulp and waste paper

SOURCE: Author's calculations. 
TABLE 2.12a Correlation coefficients of Turkish RCA values for the period 1986-8 with the RCA values of different countries for the periods 1986-8, 1983-5 and 1980-2

\begin{tabular}{llll}
\hline & $1986-8$ & $1983-5$ & $1980-2$ \\
\hline Argentina & 0.1319 & 0.1385 & 0.3344 \\
Brazil & 0.2455 & 0.1697 & 0.1996 \\
Indonesia & 0.2827 & 0.1118 & 0.0427 \\
Spain & 0.1810 & 0.2442 & 0.2959 \\
Korea & 0.4484 & 0.3809 & 0.4823 \\
Malaysia & 0.2983 & 0.2381 & 0.2644 \\
Portugal & 0.0797 & 0.1116 & 0.0908 \\
Thailand & 0.2431 & 0.3072 & 0.4226 \\
Greece & 0.5334 & 0.4094 & 0.4281 \\
\hline
\end{tabular}

SOURCE: Author's calculations.

TABLE 2.12b Correlation coefficients of Turkish RCA values for the period 1989-90 with the RCA values of different countries for the periods 1989-90, 1986-8, 1983-5 and 1980-2

\begin{tabular}{lccl}
\hline & $1989-90$ & $1986-8$ & $1983-5$ \\
\hline Argentina & 0.0806 & 0.1381 & 0.1675 \\
Brazil & 0.2725 & 0.2874 & 0.2261 \\
Indonesia & 0.2572 & 0.1958 & 0.1404 \\
Spain & 0.2828 & 0.3141 & 0.3207 \\
Korea & 0.2832 & 0.4235 & 0.3745 \\
Malaysia & 0.2757 & 0.1126 & 0.0791 \\
Portugal & 0.0210 & 0.1413 & 0.2008 \\
Thailand & 0.2900 & 0.0034 & 0.1081 \\
Greece & 0.3820 & 0.5699 & 0.3785 \\
\hline
\end{tabular}

SOURCE: Author's calculations.

and which are increasing over time 'industries with comparative advantage according to RCA criteria'.

To see where Turkey's export pattern, evidenced by RCA values, fits among those of other countries, we examine the similarity of Turkish RCA indexes to those calculated for other economies. The results are presented in Table 2.12a and $\mathrm{b}$, in which we have considered the mean RCA values for the periods $1980-2,1983-5,1986-8$ and 1989-90, and determined in Table 2.12a the correlation coefficients between Turkish RCA values for the period 1986-8 with those for period 1986-8, 19835 and $1980-2$. Table $2.12 \mathrm{~b}$ shows the correlation coefficients between 


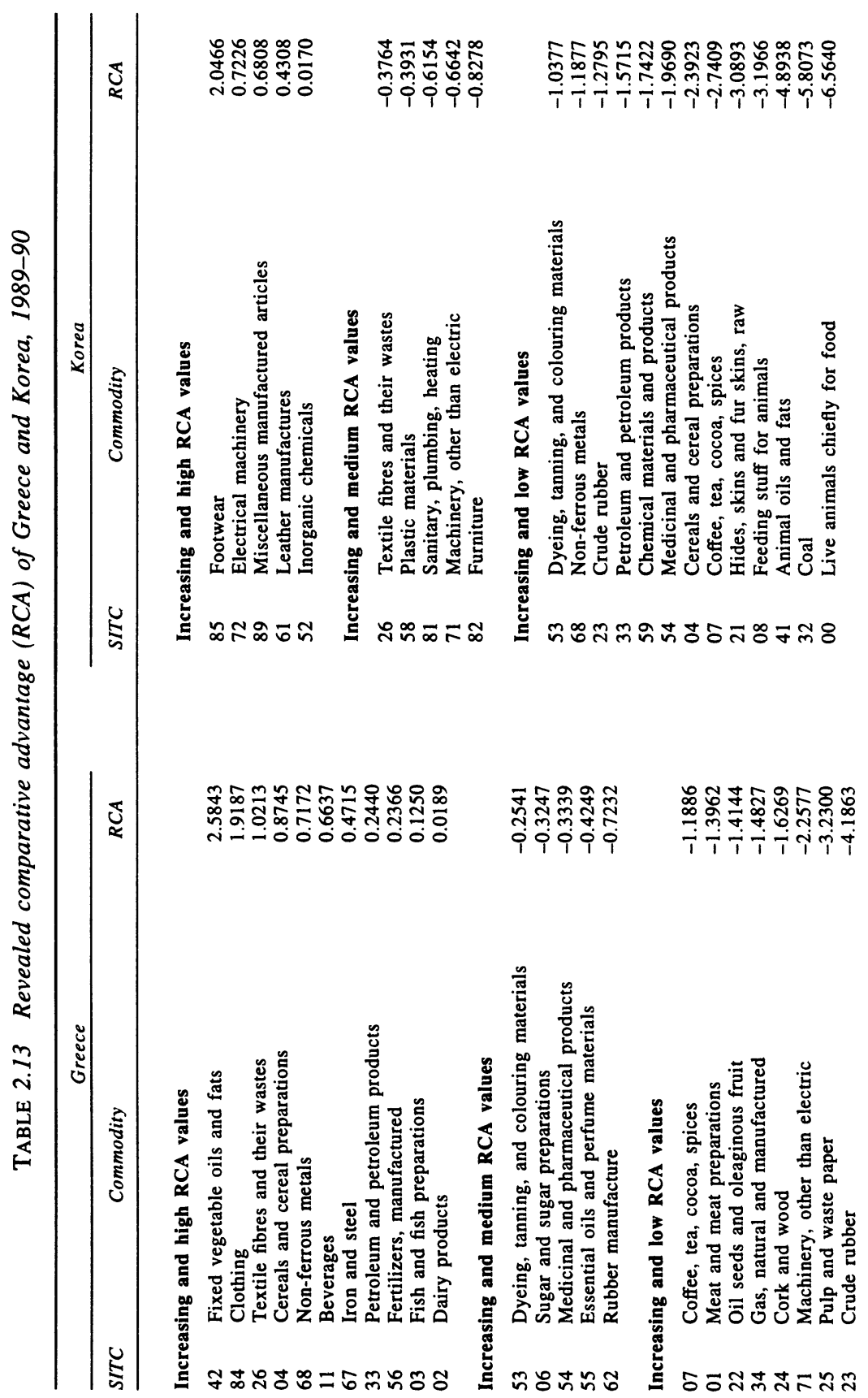




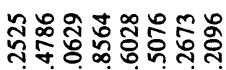

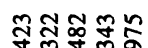

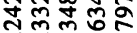
i१ịi

น 政 స్

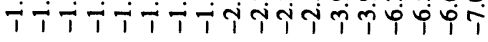
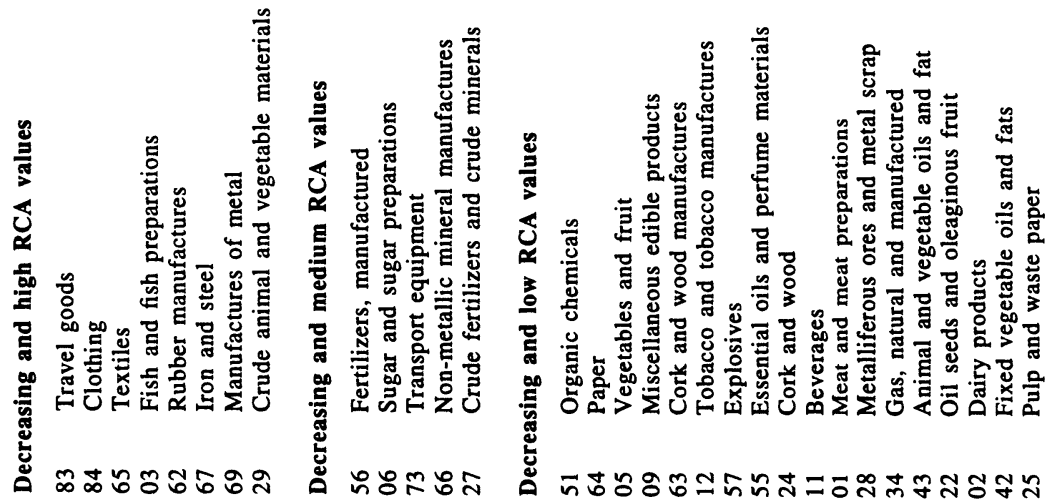

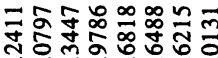

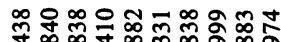

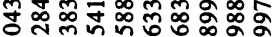
N Nभ்̆

ipipịióịi

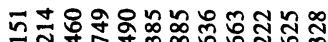

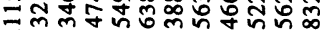

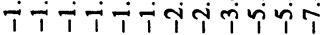
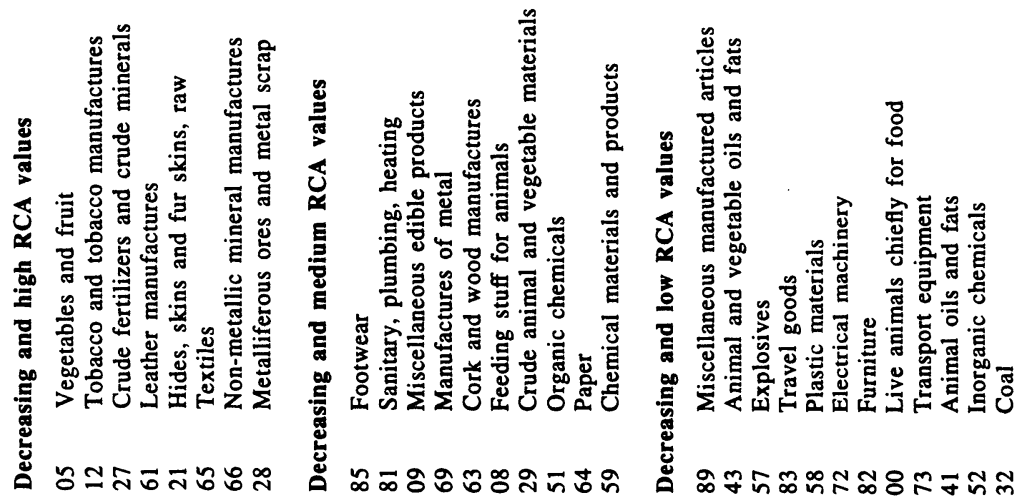
Turkish RCA values for the period 1989-90, with RCA values for other countries for the periods 1989-90, 1986-8, 1983-5 and 1980-2. From the table, it follows that Turkish exports are similar to Greek and Korean exports with a mean lag of two years. Table 2.13 shows the RCA values for Greece and Korea.

In the following, we consider the sectors which satisfy the criteria for having comparative advantage according to at least two of the three criteria (DRC, RCA and locomotive sector for either Greece or Korea) as the industries in which the country has comparative advantage. The approach leads to the conclusion that Turkey has comparative advantage in the production of the following sectors:

(i) agriculture (I-O code 1 );

(ii) iron ore mining (I-O code 7);

(iii) vegetable and animal oils and fats (I-O code 13);

(iv) other food processing (I-O code 16);

(v) clothing (I-O code 22);

(vi) leather and fur products (I-O code 23);

(vii) footwear (I-O code 24);

(viii) fertilizers (I-O code 29);

(ix) pharmaceutical products (I-O code 30 );

(x) other chemical products (I-O code 31 );

(xi) petroleum refinery (I-O code 32 );

(xii) iron and steel (I-O code 39);

(xiii) non-ferrous metals (I-O code 40);

(xiv) non-electrical machinery (I-O code 42 );

(xv) agricultural machinery (I-O code 43 ).

\section{CONCLUSION}

During the 1980s, Turkey successfully liberalized its import and export regimes. The economy-wide average level of nominal and effective protection and subsidy rates were reduced substantially over the period. However, the rates are still high - as evidenced by the nominal and effective protection rates for some of the industrial and developing countries shown in Table 2.14a-d. Furthermore, there exists considerable variation in the inter-industry distribution of incentives. The EPRs are far from being equalized among the industries. It is well known that for maximization of consumption possibilities, the EPRs must be equalized among the industries, and if some sectors are 


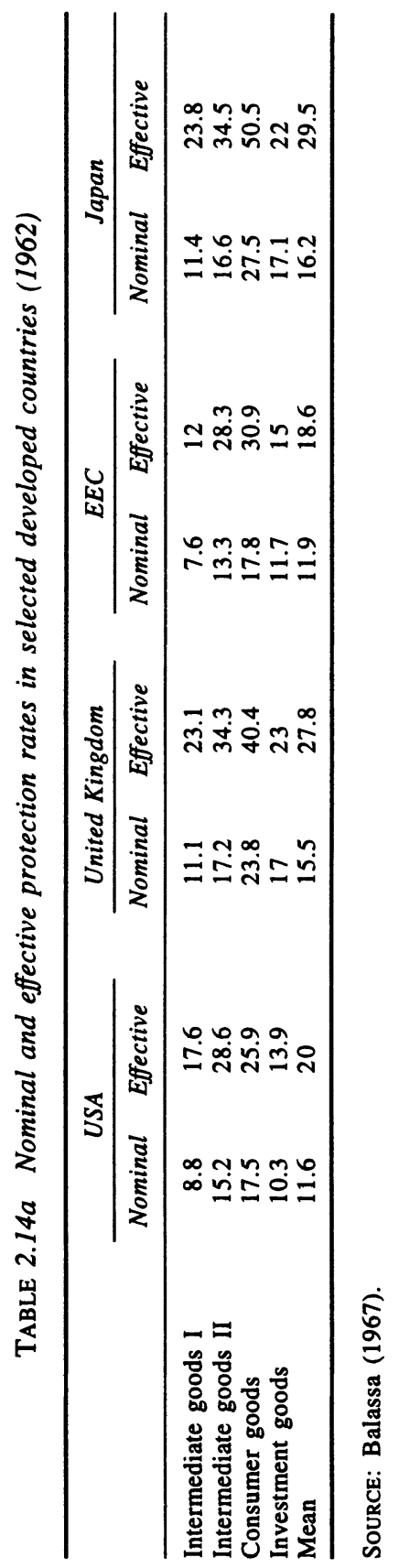


TABLE 2.14b Nominal protection rates in manufacturing sectors of selected developed countries

\begin{tabular}{lcccc}
\hline & 1925 & 1950 & 1976 & 1987 \\
\hline Germany $^{\mathrm{a}}$ & 20 & 26 & - & 7 \\
UK $^{\mathrm{a}}$ & 5 & 23 & - & 7 \\
USA $^{\mathrm{a}}$ & 37 & 14 & - & 7 \\
Greece $^{\mathrm{b}}$ & - & - & 22 & - \\
Portugal $^{\mathrm{b}}$ & - & - & 13.4 & - \\
Spain $^{\mathrm{b}}$ & - & - & 16.2 & - \\
\hline
\end{tabular}

SOURCE: ${ }^{a}$ World Bank (1991).

'Donges et al. (1982).

TABLE 2.14c Nominal and effective protection rates in Germany (1970)

\begin{tabular}{lcc}
\hline Sector name & $\begin{array}{c}\text { Nominal } \\
\text { protection }\end{array}$ & $\begin{array}{c}\text { Effective } \\
\text { protection }\end{array}$ \\
\hline Mining & 0.3 & -1.1 \\
Textiles \& clothing & 11.0 & 21.2 \\
Chemicals & 11.4 & 13.3 \\
Rubber \& plastic & 10.3 & 13.6 \\
Hides \& leather & 12.3 & 15.5 \\
Wood products & 11.0 & 15.0 \\
Glass, ceramics and cement & 12.6 & 14.9 \\
Metals & 5.5 & 20.6 \\
Metal products & 6.0 & 25.2 \\
Machinery other than electrical & 7.9 & 3.3 \\
Electrical machinery & 9.5 & 6.8 \\
Transportation equipment & 11.2 & 8.3 \\
Other manufacturing products & & \\
\hline
\end{tabular}

SOURCE: Donges et al. (1973). 


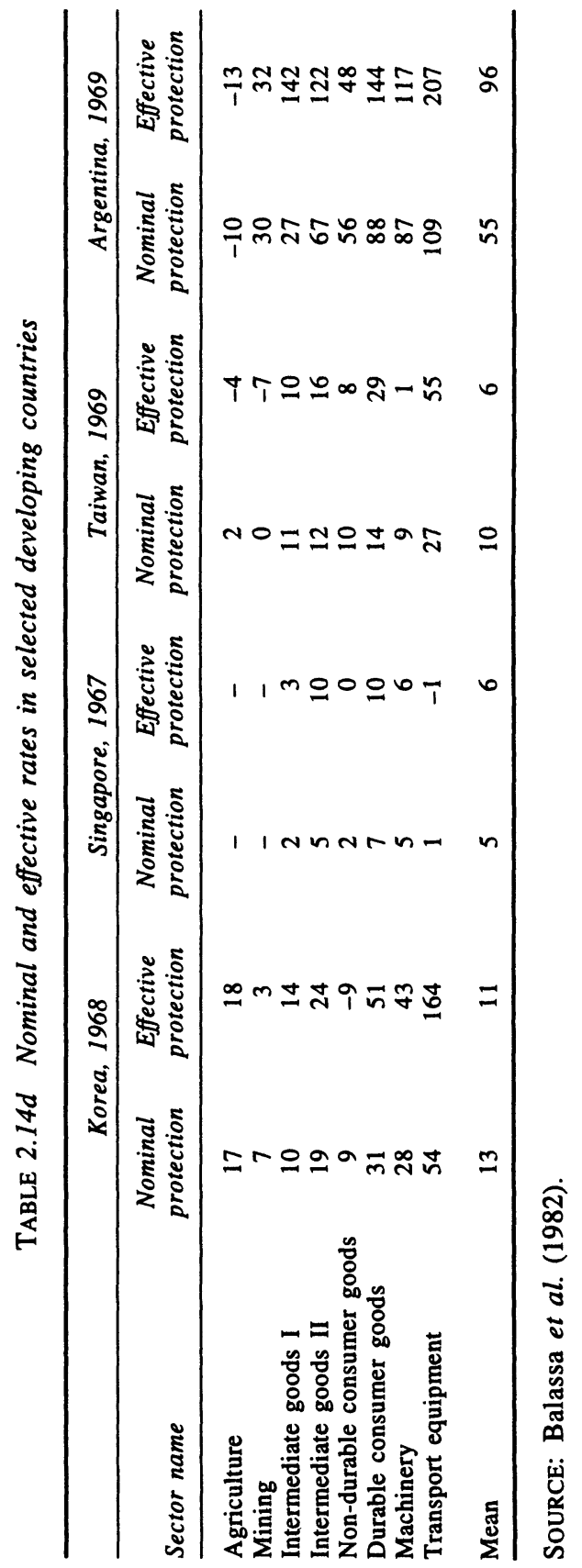


to be given priority, there must be a common difference in the EPRs of priority and non-priority sectors. There also still exists anti-export bias in the economy, and the real exchange rate must depreciate over time in order to reduce the trade deficit in the long run. Finally, the sectoral effective real exchange rates fluctuated considerably over the period, and decreased substantially over the period 1988-90. Thus, there still remains considerable room for improvement. Finally, it should be emphasized that the tariff and subsidy system prevailing in Turkey is too complicated and is not transparent. A simplification of the system is desirable. The protection and subsidy rates could be further lowered and the inter-industry dispersion of protection and subsidy rates could be further narrowed down. Such attempts should also note that frequent alterations in tariff and subsidy rates cause uncertainty for importers and exporters, creating unnecessary difficulties in planning for future production.

\section{REFERENCES}

Balassa, B. (1967), Trade Liberalization Among Industrial Countries: Objectives and Alternatives (New York: McGraw Hill).

Balassa, B. (1981), 'The Policy Experience of Newly Industrializing Economies after 1973 and the Case of Turkey', in The Role of Exchange Rate Policy in Achieving Outward Orientation of the Turkish Economy, proceedings of a conference held in Istanbul, Turkey, in July 1981, Istanbul, Meban Securities.

Balassa, B. et al. (1982), Development Strategies in Semi-Industrial Economies (Baltimore, MD: The Johns Hopkins University Press).

Baysan, Tercan and Blitzer, Charles (1988), 'Liberalizing Foreign Trade: The Experience of Turkey, Statistical Appendices' (Washington, DC: Brazil Department, World Bank).

Baysan, Tercan and Blitzer, Charles (1991), 'Turkey', in D. Papageorgiou et al. (eds), The Experience of New Zealand, Spain and Turkey, vol. 6 of Liberalizing Foreign Trade (Cambridge, Mass.: Blackwells).

Donges, Juergen B., et al. (1973), Protektion und Branchenstruktur der Westdeutschen Wirtschaft (Tubingen: J. C. B. Mohr).

Donges, J. B. et al. (1982), The Second Enlargement of the European Community: Adjustment Requirements and Challenges for Policy Reform (Tubingen: J. C. B. Mohr, Paul Siebeck).

Krueger, A. O. (1974), Foreign Trade Regimes and Economic Development: Turkey (New York: Columbia University Press).

Krueger, A. O. and Aktan, O. H. (1992), Swimming Against the Tide: Turkish Trade Reform in the 1980s (San Francisco, CA: International Center for Economic Growth, ICS Press). 
Togan, S. (1993), 1980'li Yillarda Türk Dis Ticaret Rejimi ve Dis Ticaretin Liberalizasyonu (Ankara: Turkish Eximbank).

Vollrath, T. J. (1991), 'A Theoretical Evaluation of Alternative Trade Intensity Measures of Revealed Comparative Advantage', Weltwirtschaftliches Archiv, vol. 127, pp. 265-79.

World Bank (1991), World Development Report 1991 (Oxford: Oxford University Press). 